\title{
Molecular Interaction of Novel Phytocompounds From Smilax Zeylanica (L) Against the Targeted Protein of Mosquito Vectors and Their Potential Activity
}

Chandramohan Balamurugan

Bharathiar University

Kadarkarai Murugan

Bharathiar University

Madhiyazhagan Pari ( $\sim$ madhiyazhaganpari@yahoo.com )

Arts Commerce and Science College https://orcid.org/0000-0003-3981-4530

Preethi Sivashanmugam

Bharathiar University

Praveenkumar Kumar

Bharathiar University

Lokesh Thangamani

Bharathiar University

Shanmughavel Piramanayagam

Bharathiar University

\section{Research Article}

Keywords: D7 Protein, Mosquito Saliva, dock inhibitory compounds, Mosquito-borne illnesses, solvents

Posted Date: March 1st, 2022

DOI: https://doi.org/10.21203/rs.3.rs-1407470/v1

License: (c) (i) This work is licensed under a Creative Commons Attribution 4.0 International License.

Read Full License 


\section{Author Agreement Statement}

We the undersigned declare that this manuscript is original, has not been published before and is not currently being considered for publication elsewhere.

We confirm that the manuscript has been read and approved by all named authors and that there are no other persons who satisfied the criteria for authorship but are not listed. We further confirm that the order of authors listed in the manuscript has been approved by all of us.

We understand that the Corresponding Author is the sole contact for the Editorial process.

$\mathrm{He} / \mathrm{she}$ is responsible for communicating with the other authors about progress, submissions of revisions and final approval of proofs

Signed by all authors as follows:

Balamurugan Chandramohan

Kadarakarai Murugan

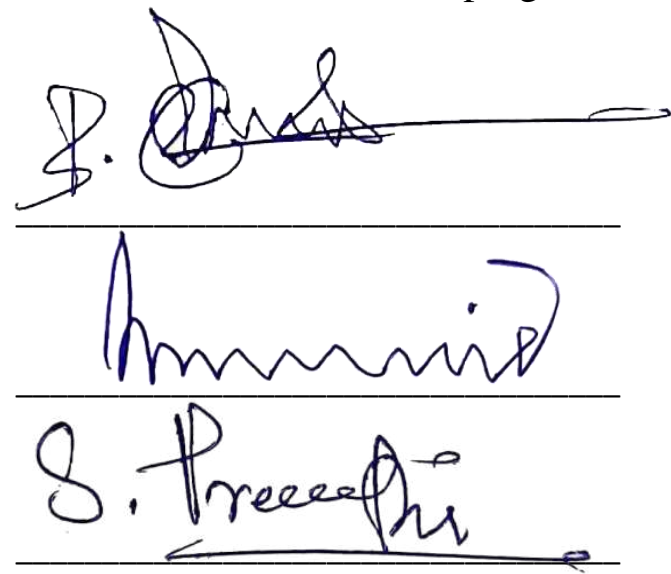

Sivashanmugam Preethi

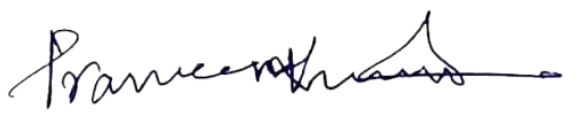

Praveen kumar

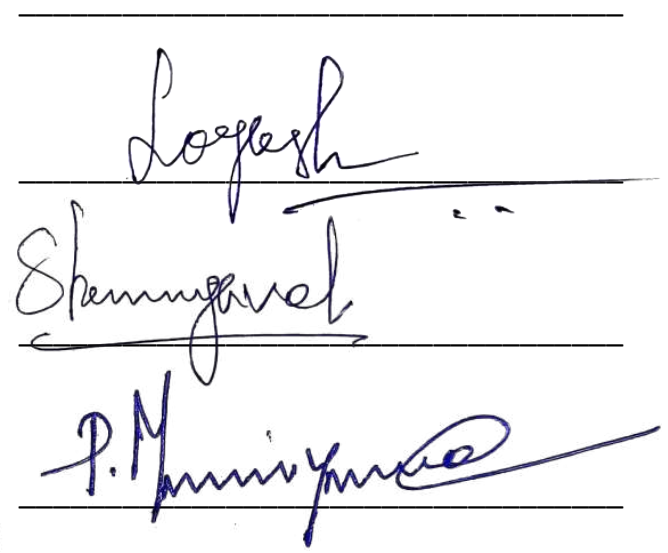

* Pari Madhiyazhagan

*Correspondig Author: Department of Zoology, J. K. K. Nataraja College of Arts and Science,
Komarapalayam, Tamilnadu, India. E-mail address: madhiyazhaganpari@ yahoo.com; phone number (+91) 9445417220 


\section{MOLECULAR INTERACTION OF NOVEL PHYTOCOMPOUNDS FROM SMILAX ZEYLANICA (L) AGAINST THE TARGETED PROTEIN OF MOSQUITO VECTORS AND THEIR POTENTIAL ACTIVITY}

Balamurugan Chandramohan ${ }^{1}$, Kadarakarai Murugan ${ }^{1}$, Pari Madhiyazhagan $^{2} *$, Sivashanmugam Preethi $^{1}$, Praveenkumar Kumar ${ }^{1}$, Lokesh Thangamani ${ }^{1}$, Piramanayagam Shanmughavel ${ }^{1}$

${ }^{1}$ Division of Entomology, Department of Zoology, School of Life Sciences, Bharathiar University, Coimbatore - 641 046, Tamil Nadu, India.

${ }^{2}$ Department of Zoology, J. K. K. Nataraja College of Arts and Science, Komarapalayam-638 183, Tamilandu, India.

\section{Correspondence}

*Corresponding author. Tel.: +919445417220.

*E-mail address: madhiyazhaganpari@yahoo.com 


\section{Abstract}

Malaria, dengue fever, filariasis, and viral encephalitis are all mosquito-borne illnesses that cause a great number of health issues across the world. Mosquitoes inject saliva into their hosts' skin to make obtaining a blood meal simpler by inhibiting hemostasis. D7 proteins are abundant in mosquito saliva and act as biogenic amine and eicosanoids scavengers. The chemical interactions of possible Smilax zeylanica compounds with mosquito-targeted D7 salivary protein and odorant binding protein were investigated. From petroleum ether, acetone, and ethanolic solvents, a total of 28 chemical components were discovered in the GC-MS study of $S$. zeylanica. Different solvents were also tested for their adulticidal and repellent properties against Anopheles stephensi, Aedes aegypti, and Culex quinquefasciatus. Among the three solvents, the ethanolic extract exhibited the highest toxic level against the three mosquito species. LC $_{50}$ of P. ether 284.92ppm, 311.97ppm and $332.76 \mathrm{ppm} ; \mathrm{LC}_{50}$ of acetone $241.97 \mathrm{ppm}, 271.61 \mathrm{ppm}$ and $304.99 \mathrm{ppm}$; and $\mathrm{LC}_{50}$ of ethanol 217.12ppm, 241.89ppm and 266.90ppm, against the three mosquito species, respectively. In repellent activity from all the solvents, complete protection was observed for up to 150 minutes against the three mosquito species. A total of 22 compounds were taken for docking studies. The compounds were subjected to docking against the three mosquitoes' D7protein. Overall, this study highlights the importance of a computational approach based on control of mosquito vectors and potential activity of biopesticides.

Keywords: D7 Protein. Mosquito Saliva. dock inhibitory compounds. Mosquito-borne illnesses. solvents 
According to the World Health Organization (WHO), mosquito-borne diseases account for about $17 \%$ of the total burden of all infectious diseases (WHO 2020a). Mosquitoes transmit a variety of diseases of medical or veterinary importance, such as malaria, filariasis, encephalitis, yellow fever, dengue, Rift Valley fever, and other diseases (Antonio-Nkondjio et al. 2019; Braack et al. 2018; Dieme et al. 2015; Parola et al. 2016; Singh et al. 2016; Tchoumbou et al. 2020; WHO, 2020b).

To understand protein-ligand interactions, molecular docking techniques are commonly utilised in the contemporary drug design process. The three-dimensional structure of the protein-ligand complex can be utilised to understand how proteins interact and conduct biological functions. As a result, one of the major difficulties in biological sciences is understanding the complete structure of protein-ligand and its complexes at the atomic level (Gaddaguti et al. 2012). Many biological processes, including signal transduction, cell control, and other acromolecular assembly, rely on molecular recognition, which includes drug-protein interactions. Understanding the interaction mechanisms and creating therapeutic approaches require determining the binding mode and affinity between the constituent molecules in molecular recognition. Because experimental methods for establishing the structures of complexes are challenging and expensive, computational methods such as molecular docking are desired for predicting probable binding modes and affinities. (Brooijmans and Kuntz 2003; Halperin et al. 2002; Shoichet et al. 2002; Kitchen et al. 2004; Muegge and Rarey 2001; Sousa et al. 2006; Kolb et al. 2009).

The ligand-based virtual screening methods using molecular similarity searching are relatively inexpensive and widely used to pool promising molecules with comparable structures, with the probability of similar biological properties, from chemical structure databases (Ebenezer et al. 2020).

Feeding is necessary for the development of eggs, as well as the transmission of most vector-borne diseases. Because saliva and transmitted infections are so closely linked, they can be treated as a single entity, and salivary proteins are currently being tested as vaccine candidates for vector-borne diseases (Kamhawi et al. 2014; Reed et al. 2016; Pingen et al. 2017). Insects have evolved the habit of feeding on blood several times, each time resulting in the emergence of essentially novel salivary proteins (Arca et al. 2017). Mosquito saliva especially, Ae. aegypti saliva contains over one hundred unique proteins that have been classified as D7 proteins, phosphatidylethanolamine binding proteins, odorant and juvenile hormone binding proteins, serpins and other protease inhibitors, a sialokinin vasodilator, nucleotidases, serine proteases, sugar digestion related proteins and other enzymes, lectins, angiopoietins, anti-microbial proteins and peptides, mucins and peritrophins, antigen 5 proteins, and many more proteins of unknown function (Chisenhall et al. 2014a,b; Bonizzoni et al. 2012).

Many researches in recent years have been noticed that the phytochemicals derived from plant resources can act as larvicides, insect growth regulators, repellents, and ovipositional attractants, having deterrent activities (Rawani et al. 2010; Matasyoh 2011; Murugan et al. 2015a). Plant extracts which are being used against different stages of mosquitoes (Bilal and Hassan 2012). Applications and uses of medicinal plants products are analyzed in each level of its manufacturing processes and used by people worldwide and no side effects and cost effective compare to other system of medicine (Gangola et al. 2017). In addition, an impressive amount of research has been published regarding the detrimental effects of pesticides, which was the main approach developed for pest control in the previous century, but which has been 
progressively replaced by the use of Biological Control Agents (BCAs) and biopesticides to provide satisfactory pest management (European Commission 2021; USDA 2021).

In this study Smilax zeylanica is chosen for the control of mosquito and the plant is useful against skin disease, pitta, insanity, diarrhea, colic, vata syphallis, gonorrhea, fever, arthritis, leucorrhoea, impotency and general weakness etc. Till now various pharmacological activities had been done on different parts of the plant like antidiabetic, antihelmentic, antioxidant, antiepileptic, pesticidal, antigonorreal (Hooda et al. 2011).

Hence, the present study was mainly an analysis of the phytochemical screening, and we carried out the bioactive compounds present in the different solvent leaf extracts of S. zeylanica using GC-MS and FTIR techniques. Also, we investigated the S. zeylanica leaf extract, which has been shown to have mosquitocidal properties against An. stephensi, Ae. aegypti, and Cx. quinquefasciatus. Furthermore, the molecular docking interaction mechanism of D7 salivary protein and odorant binding proteins of An. stephensi, Ae. aegypti, and Cx. quinquefasiatus with the selected significant ligands from the plant $S$. zeylanica was also investigated.

\section{MATERIALS AND METHODS}

\section{Collection and identification:}

The fresh leaves of Smilax zeylanica (L) were collected in the month of November from Ooty hills, Tamilnadu, India. The plant material was taxonomically identified and authenticated by Botaniocal Survery of India, Coimbatore, Tamil nadu and the voucher specimen was retained in our laboratory for further reference (Voucher No: BSI/SRC/5/23/2017Tech./335).

\section{Preparation of plant extract}

The leaves were washed with tap water, shade-dried at room temperature $\left(28 \pm 2^{\circ} \mathrm{C}\right)$ for 5 to 10 days. Since certain compounds get denatured in sunlight, it is dried under shade to avoid decomposition. $250 \mathrm{~g}$ of fresh, mature leaves were rinsed with distilled water and dried under shade. The dried leaves were put in a Soxhlet apparatus (Borosil Glass Workers Ltd, Mumbai, India) and extracts were prepared by Petroleum ether, acetone and ethanol [(Loba Chemie Pvt. Ltd., Mumbai, India. 99\% purity) (concentration of petroleum ether, acetone and ethanol is $100 \%$, extraction period 72 hours and the temperature was maintained $30-40^{\circ} \mathrm{C}$ )]. The yield extract was $100 \mathrm{~g}$ and was evaporated to dryness in rotary vacuum evaporator and the dried residues obtained were stored in airtight bottles in a refrigerator for further use.

\section{Preliminary phytochemical analysis}

The leaf petroleum ether, acetone and ethanol of S. zeylanica was subjected to phytochemical analysis was carried out for identification of tannins, terpenoids, flavonoid, alkaloid, phenol and steroids according to standard methods (Sofowara 1993; Harborne 1973; Ogbuewu 2008) is described in Table 1.

\section{Gas chromatography-mass spectrum (GC-MS) analysis}

The Clarus $680 \mathrm{GC}$ was used in the analysis employed a fused silica column, packed with Elite-5MS ( $5 \%$ biphenyl $95 \%$ dimethylpolysiloxane, $30 \mathrm{~m} \times 0.25 \mathrm{~mm} \mathrm{ID} \times 250 \mu \mathrm{m} \mathrm{df}$ ) and the components were separated using Helium as carrier gas at a constant flow of $1 \mathrm{ml} / \mathrm{min}$. The injector temperature was set at $260^{\circ} \mathrm{C}$ during the chromatographic run. The $1 \mu \mathrm{L}$ of extract sample injected into the instrument the oven temperature was as 
follows: $60{ }^{\circ} \mathrm{C}(2 \mathrm{~min})$; followed by $300{ }^{\circ} \mathrm{C}$ at the rate of $10{ }^{\circ} \mathrm{C} \mathrm{min}-1$; and $300{ }^{\circ} \mathrm{C}$, where it was held for 6 min. The mass detector conditions were: transfer line temperature $240{ }^{\circ} \mathrm{C}$; ion source temperature $240{ }^{\circ} \mathrm{C}$; and ionization mode electron impact at $70 \mathrm{eV}$, a scan time $0.2 \mathrm{sec}$ and scan interval of $0.1 \mathrm{sec}$. The fragments from 40 to $600 \mathrm{Da}$.

\section{Identification of Components}

The Identification of compounds was done based on the retention indices, molecular structure, molecular mass spectra and calculated fragmentation patterns with those stored on the computer library and also with published literature. Interpretation on mass spectrum GC MS was conducted using the database of National Institute Standard and Technology (NIST) having more than 62,000 patterns. The name, molecular weight and structure of the components of the test materials were ascertained. The relative percentage amount of each component was calculated by comparing its average peak area to the total area. The spectrums of the components were compared with the database of spectrum of known components stored in the GC-MS NIST (2008) library and WILEY9 (Van Den Dool and Kratz 1963) on-line library source was also used for matching the identified components.

\section{Fourier transforms infrared spectrophotometer (FTIR) analysis:}

The $S$. zeylanica leaf extract of petroeum ether, acetone and ethanol were prepared by dried powder used for the FTIR analysis. 10mg of the dried leaf extract powder was condensed in $100 \mathrm{mg}$ of $\mathrm{KBr}$ pellet after the each sample was loaded in the infrared spectra of the solid samples in the range 400 to $4000 \mathrm{~cm}^{-1}$ were recorded on JASCO-4100 models spectrophotometer using $\mathrm{KBr}$ pellets.

\section{Structural and Biological Data}

Publicly available structural and biological data for proteins and ligands were used throughout this work. Online bioinformatics databases such as Pub Med, PDB, Pub Chem and Drug Bank were used.

\section{Databases Accessed}

\section{Protein Data Bank}

The RCSB PDB is freely available in the public domain. It is hosted and managed by the Research Collaboratory for Structural Bioinformatics (RCSB). It can be accessed at http://www.pdb.org/pdb/home/home.do. Currently 151579 (as on 06 May, 2019) structures are available in PDB. The three dimensional structure of the template was obtained from Protein Data Bank.

\section{PubChem}

It can be accessed freely at http://pubchem.ncbi.nlm.nih.gov/.

\section{Retrieval of compounds and ligand preparation \\ Build panel}

The 3Dmodelgenerated was viewed with the help of the visualization tool Pymol (http://www.pymol.org). 


\section{Ligand preparation}

Ligand preparation used by LigPrep tools designed to prepare high quality, all-atom 3D structures for large numbers of drug-like molecules, starting with 2D or 3D structures in sdf or Maestro format.

\section{Protein selection}

Three Dimensional structures (3D) of the target proteins, namely Aedes aegypti D7\& Odorant protein (PDB ID: 3DXL, 3K1E), Anopheles stephensi D7 protein (PDBi ID: 3NGV) and Culex quinquefasciatus D7 \& Odorant protein (PDB ID: 3DXL,2L2C) were retrieved from Protein Data Bank (www.rcsb.org).

\section{Schrodinger}

Schrödinger software suite is drug designs of software using both ligand and structure-based methods. It provides superior solutions and services for the design, selection and optimization of novel drug candidates.

\section{Protein preparation}

The entire procedure can be performed in the Protein Preparation Wizard panel (Schrödinger software suite), from the Workflows menu on the main toolbar. The intended workflow in this panel is from top to bottom: fixing structures first, and then deleting unwanted chains and waters, then fixing or deleting het groups, and finally performing some optimization of the fixed structure. Glide calculations use an all-atom force for accurate energy evaluation.

\section{Receptor grid generation}

Glide searches for favorable interactions between one or more ligand molecules and a receptor molecule, usually a protein. The shape and properties of the receptor are represented on a grid by several different sets of fields that provide progressively more accurate scoring of the ligand poses. The options in each tab of the Receptor Grid Generation panel allows to define the receptor structure by excluding any co crystallized ligand that may be present, determine the position and size of the active site as it will be represented by receptor grids, and set up Glide constraints.

Ligand docking jobs cannot be performed until the receptor grids have been generated. Receptor grid

\section{Molecular docking}

Grid files represent active site of the protein that is searched when attempting to dock inhibitory compounds. All the prepared inhibitory compounds were docked against to the grid generated target proteins. Molecular docking was performed using Glide module from Schrodinger suite.

The inhibitory compounds used for docking, it was initially screened using Standard Precision (SP) docking followed by Extra Precision (XP) docking. The XP method weeds out false positives and provides better correlation between good poses and good scores. Since XP mode is a refinement tool designed for use 
only one inhibitory compounds poses, large sets of compounds are screened by the SP mode. Ultimately, optimization of the compound structures in the field of the receptor was done and the compounds were scored. Glide was run in rigid mode; the latter automatically generates conformations for each inhibitory compounds. The combination of position and orientation of inhibitory compounds relative to the target protein receptor, along with its conformation is referred to as an inhibitory compounds pose. The inhibitory compounds poses that Glide generates pass through a series of hierarchical filters that evaluate the inhibitory compounds interaction with the target proteins. The initial filters validate the spatial fit of the inhibitory compounds to the defined active site of the target proteins. Final scoring is then carried out on the energy-minimized poses. Scoring function is used to score the poses. Glide Score was selected as the scoring function to rank the poses of each inhibitory compound. Finally, Glide XP Visualizer panel is used to Visualizing the docking complex.

\section{Mosquito Rearing}

Experiments were conducted using laboratory-rearedpathogen-free strain strains of An. stephensi, Ae. aegypti, and $C x$. quinquefasciatus. Colonies were originally established as described by Dinesh et al. (2015) respectively. Eggs of An. stephensi, Ae. aegypti and Cx. quinquefasciatus were provided by National Centre for Disease Control (NCDC), filed station of Mettupalayam, Coimbatore (Tamil Nadu, India) using an “O”type brush. These eggs were brought to the laboratory and were transferred to $18 \times 13 \times 4 \mathrm{~cm}$ size enamel trays containing $500 \mathrm{ml}$ of water and kept for larval hatching. Mosquito larvae were maintained at $27 \pm 2{ }^{\circ} \mathrm{C}, 75-85 \%$ R.H.; (relative humidity), under a photoperiod of 14:10 (light/dark). Mosquito larvae were fed daily with $5 \mathrm{~g}$ of ground dog biscuits (Pedigree, USA) and hydrolyzed yeast (Sigma-Aldrich, Germany) in a 3:1 ratio. Newly emerged larvae and pupae and 2-day-old adults were collected and used in the experiments.

\section{Adulticidal bioassay}

Adulticidal experiments were performed following the methods reported by Suresh et al. (2015). The leaf extract of S. zeylanica was tested at 100, 200, 300, 400, and $500 \mathrm{ppm}$. For each tested dosage, five replicates were carried out. The leaf extract were applied on Whatman no. 1 filter paper (size $12 \times 15 \mathrm{~cm})$ lining a glass holding tube (diameter $30 \mathrm{~mm}$; length $60 \mathrm{~mm}$ ). In control treatments, filter paper was treated with either the same volume of distilled water or in aqueous solution. In each test, 20 mosquito females were gently transferred into another glass holding tube. The mosquitoes were allowed to acclimatize in the tube for $1 \mathrm{~h}$ and then exposed to a test tube lined with treated or control paper for $1 \mathrm{~h}$. At the end of exposure period, the mosquitoes were transferred back to the original holding tube, kept for a 24-h recovery period, then mortality was recorded. A pad of cotton soaked with $10 \%$ (w:v) glucose solution was placed on the Sugar-fed adult female mosquitoes ( 5 to 6 days old) were used. The biopesticides were diluted with acetone to make different concentrations. The diluted biopesticides were impregnated on filter papers $(140 \times 120 \mathrm{~mm})$. A blank paper consisting of only ethanol was used as control. The papers were left to dry at room temperature to let the ethanol evaporate overnight. Impregnated papers were prepared fresh prior to testing. The bioassay was conducted in an experimental kit consisting of two cylindrical plastic tubes both measuring $125 \times 44 \mathrm{~mm}$ following the method of WHO (1981). One tube served to expose the mosquitoes to the biopesticides and another tube was used to hold the mosquitoes before and after the exposure periods. The impregnated papers were rolled and placed in the exposure tube. Each tube was closed at one end with a 16-mesh wire screen. Sucrose-fed and blood-starved mosquitoes (20) were released into the tube, and the mortality effects of the bio pesticides were observed every $10 \mathrm{~min}$ for a $3 \mathrm{hrs}$ 
exposure period. At the end of 1, 2 and $3 \mathrm{hrs}$ exposure periods, the mosquitoes were placed in the holding tube. Cotton pads soaked in $10 \%$ sugar solution with vitamin B complex was placed in the tube during the holding period for $24 \mathrm{hrs}$. Mortality of the mosquitoes was recorded after $24 \mathrm{hrs}$. The above procedure was carried out in triplicate for bio pesticides of each concentration. The lethal concentrations (lethal dose $\mathrm{LC}_{50}, \mathrm{LC}_{90}$ ) were calculated by probit analysis (Finney 1971).

\section{Repellent activity}

The repellency of the S. zeylanica extracts against An. stephensi, Ae. aegypti and Cx. quinquefasciatus was evaluated by using the percentage of protection in relation dose method. Three days old blood starved female An. stephensi, Ae. aegypti and Cx. quinquefasciatus mosquitoes (100) were kept in to net cage $(45 \mathrm{~cm} \times 30 \mathrm{~cm} \times 45 \mathrm{~cm})$. Two cages with hungry mosquitoes for test and control were kept aside. The volunteer had no contact with lotions, perfumes, oils or perfumed soap on the day of assay. The arms of the volunteer skin washed and cleaned with ethanol and ethanol served as control. After air trying, the arms of the volunteer, only $25 \mathrm{~cm} 2$ dorsal side of the skin on each arm was exposed and the remaining area covered by rubber gloves. The different concentrations of crude extracts were applied. Ae. aegypti was tested during the day time from 07.00 to $17.00 \mathrm{~h}$, while $C x$. quinquefasciatus and An. stephensi were tested during the night from 19.00 to $05.00 \mathrm{~h}$. The control and treated arm were introduced simultaneously into the mosquito cage, and gently tapping the side on the experimental cage, the mosquitoes were activated. The volunteer conducted their test of each concentration by inserting the treated and control arm into cages at a same time for one full minute for every $5 \mathrm{~min}$. The experiment was trialed 5 times. The mosquitoes that land on the hand were recorded and then shaken off before imbibes any blood. The percentage of repellency was calculated by formula.

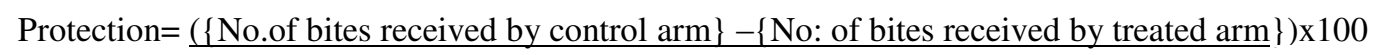

No. of bites received by control arm

\section{Data analysis}

The average mosquito larvicidal, pupicidal and adulticidal toxicity data were subjected to probit analysis. $\mathrm{LC}_{50}$ and $\mathrm{LC}_{90}$ were calculated using the method by Finney (1971). All data were analyzed using the SPSS Statistical Software Package version 16.0. The mosquito ovicidal, larvicidal and adulticidal percentage data were analyzed also subjected to ANOVA followed by Tukey's HSD test. A probability level of $\mathrm{P}<0.05$ was used for the significance of differences between values.

\section{RESULTS AND DISCUSSION}

\section{Primary phytochemicals screening of Smilax zeylanica}

Tannins: A green precipitate was observed in all the extracts indicating thereby the presence of tannins in all three solvent extracts analysed.

Terpenoids: A deep red color was observed in ethanol extracts out of three solvents.

Flavonoids: A yellow coloration was also observed in all the solvent extracts indicating thereby the presence of flavonoids in all three solvent extracts screened. 
Alkaloids: A yellow precipitate was observed in two solvent extracts except petroleum ether extract and confirming thereby the presence of alkaloids.

322 Phenolic: An intense colour was observed in all solvent extracts and confirming thereby the presence of phenolic.

324 Steroids: A reddish brown ring at the interface was observed in all the three solvent extract of S. zeylanica and indicating the presence of steroids in this plant. (Given in table 2)

S. zeylanica is contained chemicals such as diosgenin, smilagenin, sarsasapogenin, $\beta$-sitosterol, hydroxytyrosol, trans-iso-eugenol and squalene (Murali et al. 2012; Rajesh and Perumal 2014). Recently, Padma et al. (2019) reported that the phytochemical characterization, ethanolic leaves extracts of S.marianumare revealed the presence of alkaloids, flavonoids, tannins, phenol, cardiac glycosides, anthraquinones and also revealed the absence of saponins, terpenoids. The results agree with the finding of Dhawan and Gupta et al. (2017) observed the different phyto-constituents such as alkaloids, flavonoids, saponins, steroids and tannins were present in the acetone, chloroform, distilled water, ethyl acetate, hexane and methanol extract of Datura metel. Pandey et al. (2017) noted that the following phytochemicals such as alkaloid, saponin, protein, quinone, sterols, cardiac glycoside, flavonoids, tannin, terpenoid, reducing sugar in the methanol extract of A. vulgaris and G. fragrantissima.

\section{GC-MS analysis}

In the present study, GC-MS chromatogram was detected in the following three solvent (petroleum ether, acetone and ethanol) leaf extracts of $S$. zeylanica (illustrated in fig. 1-3). The identification of the phytochemical compounds present in the various solvent extract of $S$. zeylanica was confirmed based on their retention time (RT), molecular formula, molecular weight, and percentage (\% area), Forward, Reverse and biological properties are given in Table 3 to 5 .

The GC-MS analysis of petroleum ether leaf extracts of S.zeylanica revealed the presence of 10 different bioactive compounds namely, Phytol; 3,7,11,15-Tetramethyl-2-Hexadecen-1-ol, N-Hexadecanoic Acid, Pentadecanoic Acid, 1-Hexyl-2-Nitrocyclohexane, E-3-Pentadecen-2-ol, Hexadecane 1-Chloro-, Tritetracontane, Heptacosane, 1-Chloro and Vitamin E respectively, are shown in (Table 3). The acetone leaf extract of S.zeylanica showed the presence of 8 different bioactive compounds namely, 2-(2-Piperidin-1-yl-Ethyl)Pyridine, 3-Acetoxydodecane, N-Hexadecanoic Acid, Hexadecanoic Acid,2-Bromo-, Pentanoic Acid,2(Aminooxy)-, Bicyclo[3.2.1] oct-3-en-2-one,3,8-Dihydroxy-1-Methoxy-7-(7-Methoxy-1,3-, $\quad$ 2-Isopropyl-5Methylcyclohexyl3-(1-(4 Chlorophenyl)-3 Oxobutyl)-C, 1-Monolinoleoylglycerol Trimethylsilyl Ether respectively Presented in the Table 4. Ethanol extract of $S$. zeylanica contains 10 different secondary compounds namely, 2-Pentenal, 2-Methyl, 4,4'-Biscyclohexanone, 2,2',6,6'-Tetramethyl-, 6-Methyl-7-oxo-1,7Dihydro-Triazolo (4,3-B) Triazine, 6-Acetyl-Beta.-D-Mannose, 4-Ethyl-2-Hydroxycyclopent-2-en-1-one, Cyclopropanetetradecanoic Acid, 2-Octyl-, Mehyl Ester, D-Galactitol,1,3,4,5-Tetra-O-Methyl-,Diacetate, EicosanoicAcid, 2,3-bis[(Trimethylsilyl)oxy]Propyl Ester, 11-Eicosenoic Acid, Trimethylsilyl Ester, Ethanol, 1(Methylenecyclopropyl)-1-(Methylene-1-Trimethylsilylcy respectively, were shown in (Table 5). We observed that GC-MS analysis indicated the ethanol extract had present in the maximum bioactive compounds where as compared with other solvent extract of petroleum ether followed by acetone extract respectively. Table 6 Showed the biological properties listed in the presence of various phytochemical compounds from petroeum ether, acetone and ethanol leaf extract of S. zeylanica. 
361

362

363

364

365

366

367

368

369

370

371

372

373

374

375

376

377

378

379

380

381

382

383

384

385

386

387

388

389

390

391

392

393

394

395

396

397

398

399

400

The FTIR spectrum analysis using for the identification of major peaks correspondence to the functional groups and bioactive active components were present in the petroleum ether, acetone and ethanol leaf extract of $S$. zeylanica. In the present results, FT-IR analysis observed the peak at 3352, 2962, 1707, 1366, 1229, 1027 and $681 \mathrm{~cm}^{-1}$ which correspond to confirmed the presence of alcohol, Amine group, Carbocyclic acids, Phenol, Ether, Alkyl aryl ether and Alkene (Table 7 and Fig. 4). Kalaichelvi and Dhivya (2017) reported that FT-IR spectrum confirmed the presence of alcohols, phenols, alkanes, alkynes, alkyl halides, aldehydes, aromatics, nitro compounds and amines in petroleum ether extract of Micrococca mercurialis. Starlin et al. (2012) reported the ethanolic extract of Tylophora pauciflora observed the peak at 2800, 2862.36 and $2926.01 \mathrm{~cm}^{-1}$ which correspond to lipids, alkanes, and hydroxyl compounds and the peak at 1730, and 1708 $\mathrm{cm}^{-1}$ shows the presence of ester carbonyl and unsaturated carbonyl groups. The strong absorption bands at 2931 and $1458 \mathrm{~cm}^{-1}$ are due to $\mathrm{CH}$ and $\mathrm{CH}_{2}$ groups respectively.

\section{Molecular interaction studies of inhibitory compounds against target proteins}

One key methodology ideated during 1980 of docking of small molecules to protein binding sites remains a highly active area of research especially in conditions when the structure of a target and its active or binding site is available, therefore, primarily it was used as a hit identification tool. Further validated compounds used for wet lab practice. Specific features of protein-ligand docking methods and several applications were used here in combination with hit identification and lead optimization (Bajorath 2015).

The compounds taken from the GCMS studies and retrieved from the pubchem database and used for docking studies. The list of compounds retrieved is providing in the (Table 8). Totally 23 screened compounds were subjected for docking against Ae. Aegypti D7 protein and Cx. quinquefasciatus (PDB ID: 3DXL). Initially, based on scoring function, all compounds were screened. Glide score of 6-Acetyl-.Beta.-D-Mannose was -8.75. 6-Acetyl-.Beta.-D-Mannose compound have good glide score and also potentially interacted with D7 (Fig. 5). Out of 23 compounds 6-Acetyl-.Beta.-D-Mannose docking score was -8.75 that formed 8 hydrogen bonds interacting withGLU18, GLU18, ARG270, ARG15, THR14, ARG267ARG267,ARG267 residue and Top ranking compounds showed good glide score (Table 9).

Similarly, docking of potential inhibitory compounds against Anopheles stephensi D7 protein (PDB ID: 3NGV). Glide score of Bicyclo[3.2.1]oct-3-en-2-one, 3,8-Dihydroxy-1-Methoxy-7-(7-Methoxy-1,3 was -7.24 and one $\mathrm{H}$ bond formed in between $\mathrm{H}$ atom of Bicyclo[3.2.1]oct-3-en-2-one, 3,8-Dihydroxy-1-Methoxy-7-(7Methoxy-1,3. ARG199 and CYS55 residue of D7 protein (Fig. 6). Top ranking compounds showed good glide score and also more number of H-bonds (Table 10).

Docking of potential inhibitory compounds against Aedes aegypti Odorant protein (PDB ID: 3K1E). Glide score of Bicyclo[3.2.1]oct-3-en-2-one, 3,8-Dihydroxy-1-Methoxy-7-(7-Methoxy-1,3 was -10.89 and one $\mathrm{H}$ bond formed in between $\mathrm{H}$ atom of Bicyclo[3.2.1]oct-3-en-2-one, 3,8-Dihydroxy-1-Methoxy-7-(7-Methoxy-1,3 and HIE111 residue of D7 protein (Fig. 7). Top ranking compounds showed good glide score and also more number of H-bonds (Table 11).

Docking of potential inhibitory compounds against Culex quinquefasciatus Odorant protein (PDB ID: 2L2C). Glide score of Bicyclo [3.2.1] oct-3-en-2-one, 3,8-Dihydroxy-1-Methoxy-7-(7-Methoxy-1,3 was -10.45 (Fig. 8). Here, as per scoring and interaction, top 5 compounds were selected which showed a score range of - 
7.82 to -10.45 . Top ranking compounds showed good glide score and also more number of H-bonds given in (Table 12).

However D7 proteins are directly responsible for insecticide resistance or simply closely-associated markers, their role in mosquito blood-feeding makes this over expression phenotype relevant to malaria transmission. Real-time quantitative PCR analyses of mosquitoes collected post-IRS detected instances of extremely highlevels of D7r2 and D7r4 expression. D7 proteins are estimated to compose at least 5-20\% of salivary protein Calvo et al. (2006).

Our results compared with recently studied that the D7 protein from the Aedes aegypti mosquito was observed to bind dengue virions and envelope protein, suggesting that this family of proteins may have a broader range of associated phenotypes Conway et al. (2016). In addition Isaacs et al. (2018) investigated the insilico docking studies confirmed that bendiocarb could be manually positioned in the D7r4 salivary protein against An. gambiae, Although $\mathrm{D} 7 \mathrm{r} 2$ and $\mathrm{D} 7 \mathrm{r} 4$ are relatively distantly related, sharing only $32 \%$ sequence identity, they align with only a single one residue insertion in the former vs the latter.

Further present findings agree with those earlier studies of Carey et al. (2010) reported that the some plant-derived repellents have been found to target multiple odorant receptors. Expected to be less susceptible to resistance than compounds acting on a single receptor (Norris and Coats 2017). Thireou et al. (2018) studied a fast and efficient virtual screening protocol for discovery of novel bioinspired synthetic mosquito repellents with lower volatility and, in all likelihood, increased protection time as compared with their plant-derived parental compounds.

\section{Adultcidal activity}

Adulticidal activity of p.ether, acetone and ethanol leaf extract of $S$. zeylanica against adult of An. stephensi, Ae. aegypti, and Cx.quinquefasciatus. among the leaf extract of S. zeylanica was found to cause a mosquito knockdown after exposure to various concentrations paralysis and inactive. The results of the adulticidal activity of p.ether leaf extract of S. zeylanica against adults of An.stephensi, Ae.aegypti and Cx. quinquefasciatus led to $\mathrm{LC}_{50}$ and $\mathrm{LC}_{90}$ value of An. Stephensi 284.92 (678.15) ppm; Ae. aegypti 311.97 (700.05)ppm; Cx. quinquefasciatus 332.76 (715.34ppm), respectively (given in table 13).

Table 14 provides adult mortality of acetone extract of S. zeylanica, showed An. stephensi, as measured by $\mathrm{LC}_{50}$ and $\mathrm{LC}_{90}$ values of 241.97and 634.40ppm; Ae. aegypti $\mathrm{LC}_{50}$ value was $271.61 \mathrm{ppm}$ and $\mathrm{LC}_{90}$ value was $662.33 \mathrm{ppm} ; C x$. quinquefasciatus $\mathrm{LC}_{50}$ value was $304.99 \mathrm{ppm}$ and $\mathrm{LC}_{90}$ value was $703.03 \mathrm{ppm}$, respectively. The subsequent record at the end of a 24 hrs holding period revealed mortality values of, p.ether, acetone, and ethanol was $79.2 \%, 76.4 \%$, and $72.3 \%$, at $500 \mathrm{ppm}$, respectively.

Table 15 shows the ethanol leaf extracts of $S$. zeylanica showed statistically significant toxicity on the adult of An. stephensi, Ae. aegypti and Cx. quinquefasciatus. The mortality rates were directly proportional to concentration of the $S$. zeylanica leaf extracts used. The highest adulticidal activity was observed in the $A n$. stephensi followed by, Ae. aegypti, and Cx. quinquefasciatus. Th An. stephensi, as measured by $\mathrm{LC}_{50}$ and $\mathrm{LC}_{90}$ values of 217.12 and 578.86ppm; Ae.aegypti $\mathrm{LC}_{50}$ value was $241.89 \mathrm{ppm}$ and $\mathrm{LC}_{90}$ value was $607.15 \mathrm{ppm}$; $C x$. quinquefasciatus $\mathrm{LC}_{50}$ value was $266.90 \mathrm{ppm}$ and $\mathrm{LC}_{90}$ value was $642.43 \mathrm{ppm}$, respectively.

Present findings also agree with those from earlier studies of Amerasan et al. (2012) who have reported that the all extracts showed moderate adulticidal effects; however, the highest adult mortality observed was found in methanol extract. The $\mathrm{LC}_{50}$ and $\mathrm{LC}_{90}$ values of $C$. tora leaf extract against adulticidal activity of 
(hexane, chloroform benzene, acetone, and methanol) Cx. quinquefasciatus, Ae. aegypti, and An. stephensi were the following: $C x$. quinquefasciatus $\mathrm{LC}_{50}$ values were $338.81,315.73,296.13,279.23$, and 261.03 ppm and $\mathrm{LC}_{90}$ values were 575.77, 539.31, 513.99, 497.06, and 476.03 ppm; Ae. aegypti $\mathrm{LC}_{50}$ values were 329.82, 307.31, 287.15, 269.57, and 252.03 ppm and $\mathrm{LC}_{90}$ values were 563.24, 528.33, 496.92, 477.61, and 448.05 ppm; and $A$. stephensi $\mathrm{LC}_{50}$ values were 317.28, 300.30, 277.51, 263.35, and $251.43 \mathrm{ppm}$ and $\mathrm{LC}_{90}$ values were 538.22, 512.90, 483.78,461.08, and $430.70 \mathrm{ppm}$, respectively. Pratheeba et al. (2015) reported that the adulticidal activities of acetone, hexane and chloroform extracts of Ocimum gratissimum against filariasis vector $C x$. quinquefasciatus.

\section{Repellent activity of S. zeylanica leaf extracts against An. Stephensi, Ae. aegypti and Cx. quinquefasciatus}

In the present study showed that repellent of S. zeylanica origin do not pose hazards of toxicity to human and domestic animals and are easily bio-degradable. Natural products are safe for human when compare with synthetic compounds certain natural products have been investigated for repellent against mosquitoes. The present investigation results suggest that among the three solvent extracts such as p.ether, acetone and ethanol leaf extract of $S$. zeylanica exhibited better protection against the bite from An. stephensi, Ae. aegypti and Cx. quinquefasciatus. The ethanol had the maximum protection followed by acetone and p.ether leaf extract of $S$. zeylanica against An. stephensi, Ae. aegypti and Cx. quinquefasciatus respectively. The skin repellent activity of petroleum ether, acetone and ethanol leaf extract of S. zeylanica against An. Stephensi, Ae. aegypti and Cx. quinquefasciatus. When the repellent activity of three different concentrations were tested $\left(0.5,1.0,1.5 \mathrm{mg} / \mathrm{cm}^{2}\right)$ on volunteer skin (forearm). The result revealed that the protection observed at $1.5 \mathrm{mg} / \mathrm{cm}^{2}$ was more protection than the other two concentrations. Among the tested ethanol extract provided significant repellency against $A n$. Stephensi followed by Ae. aegypti and Cx. quinquefasciatus respectively. The higher concentration of $1.5 \mathrm{mg} / \mathrm{cm}^{2}$ provided $100 \%$ protection up to 210 minutes. The lower concentration of $0.5 \mathrm{mg} / \mathrm{cm}^{2}$ and $1.0 \mathrm{mg} / \mathrm{cm} 2$ provided $100 \%$ protection up to 180 minutes, respectively (Table:16-18).

Repellent is known to play important role in preventing the vector borne disease by reducing manvector contact. Synthetic chemicals and insecticides used for control of vectors are causing irreversible damage to the eco-system, as some of them are non-degradable in nature. The plant based repellents may have good role in reducing the biting nuisance and infections by preventing the man-fly contact (Fradin and Day 2002; Spero et al. 2008) and to preclude any adverse effect that could emanate from the use of synthetic repellents (Goodyer and Behrens 1998).

Our results agree with some previous studies, Hassan et al. (2015) reported that the methanol, acetone and petroleum ether extracts of Ocimum basilicum and Glycyrrhiza glabra were screened for their repellency effect against $C x$. pipiens. Murugan et al. (2012) Larvicidal, pupicidal, repellent and adulticidal activity of Citrus sinensis orange peel extract against Anopheles stephensi, Aedes aegypti and Culex quinquefasciatus. AlSarar et al. (2014) evaluated that the Mentha longifolia L, and Lavandula dentata L essential oils had excellent insecticidal and repellent activity against adult females of Culex pipiens L. Further, Sritabutra and Soonwera (2013) reported that repellent activity of herbal essential oils against Aedes aegypti and Culex quinquefasciatus.

Lastly, Govindarajan et al. (2011) studied the repellent activities of crude benzene and ethyl acetate extracts of leaf of Ervatamia coronaria and Caesalpinia pulcherrima were assayed for their toxicity against An. stephensi, Ae. aegypti and Cx. quinquefasciatus. 
In this study, we have determined the compound present in S. zeylanicawas screened for their mosquitoes by docking them with D7 and Odorant Binding proteins. identified and characterised binding sites of target odorant binding proteins (OBPs) D7 and from An. stephensi, A. aegypti, and Cx. quinquefasciatus. The molecular docking study clearly states that the D7 protein and plant components had excellent interactions between them. Furthermore, It was investigated whether these compounds could be used as adulticidal and repellents against the three mosquito species, and significant results were obtained. Overall, the study concluded that as the identified ligands are of phytochemical origin, it may be presumed that they are safer in the environment as well as less toxic to targeted organisms.

492

493

\section{Acknowledgement}

494

The authors are grateful to the Head of the Department at Bharathiar University, Coimbatore, Tamilnadu, India for providing lab facilities to carry out the major part of the experiments.

496

497

\section{Conflict of Interest}

498

We wish to confirm that there are no known conflicts of interest associated with this publication and there has

499 been no significant financial support for this work that could have influenced its outcome.

500

501

\section{References}

502

Al-Sarar AS, Hussein HI, Abobakr Y (2014) Fumigant toxicity and antiacetylcholinesterase activity of Saudi Mentha longifolia and Lavandula dentata species against Callosobruchus maculatus (F.) (Coleoptera: Bruchidae). Turk. J Entomol 38:11-18. https://doi.org/10.16970/ted.10646 elimination. Parasit Vectors 12:1-23. https://doi.org/10.1186/s13071-019-3753-8.

Amerasan D, Murugan K, Kovendan K, Kumar PM, Panneerselvam C, Subramaniam J, William SJ, Hwang JS (2012) Adulticidal and repellent properties of Cassia tora Linn. (Family: Caesalpinaceae) against Culex quinquefasciatus, Aedes aegypti, and Anopheles stephensi. Parasitol Res 111(5):1953-1964. https://doi.org/10.1007/s00436-012-3042-3

Ara I, Bukhari NA, Solaiman D, Bakir MA (2012) Antimicrobial effect of local medicinal plant extracts in the Kingdom of Saudi Arabia and search for their metabolites by gas chromatography-mass spectrometric (GC-MS) analysis. J Medici Plants Res 6(45):5688-5694. https://doi.org/10.5897/JMPR12.288

Arca B, Lombardo F, Struchiner CJ, Ribeiro JM (2017) Anopheline salivary protein genes and gene families: an evolutionary overview after the whole genome sequence of sixteen Anopheles species. BMC Genom 18:1-27. https://doi.org/10.1186/s12864-017-3579-8

Bajorath, Jurgen (2015) Computer-aided drug discovery. F1000 Research, 4(F1000 Faculty Rev):630. https://doi.org/10.12688/f1000research.6653.1

Bilal H, Hassan SA (2012) Plants secondary metabolites for mosquito control. Asian Pac J Trop Dis 2:168-168. https://doi.org/10.1016/S2222-1808(12)60038-3 
Bonizzoni M, Dunn WA, Campbell CL, Olson KE, Marinotti O, James AA (2012) Complex modulation of the Aedes aegypti transcriptome in response to dengue virus infection. PLoS One 7(11):e50512. https://doi.org/10.1371/journal.pone.0050512

Braack L, De Almeida APG, Cornel AJ, Swanepoel R, De Jager C (2018) Mosquito-borne arboviruses of African origin: review of key viruses and vectors. Parasit Vectors, 11: 1 - 26. https://doi.org/10.1186/s13071-017-2559-9

Brooijmans N, Kuntz ID (2003) Molecular recognition and docking algorithms. Ann Rev Biophy Biomol Struc 32:335-373. https://doi.org/10.1146/annurev.biophys.32.110601.142532

Calvo E, Mans BJ, Andersen JF, Ribeiro JM (2006) Function and evolution of a mosquito salivary protein family. J Biol Chem 281(4):1935-1942. https://doi.org/10.1074/jbc.M510359200

Carey AF, Wang GR, SU CY, Zwiebel LJ, Carlson JR (2010) Odorant reception in the malaria mosquito Anopheles gambiae. Nat 464:U66-U77. https://doi.org/10.1038/nature08834

Chisenhall DM, Christofferson RC, Mccracken MK, Johnson AM, Londono-Renteria B, Mores CN (2014b) Infection with dengue-2 virus alters proteins in naturally expectorated saliva of Aedes aegypti mosquitoes. Parasit Vect 7:252. https://doi.org/10.1371/journal.pntd.0004941

Chisenhall DM, Londono BL, Christofferson RC, Mccracken MK, Mores CN (2014a). Effect of dengue-2 virus infection on protein expression in the salivary glands of Aedes aegypti mosquitoes. The Americ Soc Trop Med Hyg 90(3):431-437. https://doi.org/10.4269/ajtmh.13-0412

Conway MJ, Londono-Renteria B, Troupin A, Watson AM, Klimstra WB, Fikrig E, Colpitts TM (2016) Aedes aegypti D7 saliva protein inhibits dengue virus infection. PLoS Negl Trop Dis 10(9):e0004941. https://doi.org/10.1371/journal.pntd.0004941

Costa MA, Xia ZQ, Davin LB, Lewis NG (1999) Toward engineering the metabolic pathways of cancerpreventing lignans in cereal grains and other crops in Phytochemicals in Human Health Protection. Nut Plant Def pp.67-87. Springer, Boston, MA. https://doi.org/10.1007/978-1-4615-4689-4_4

Dandekar R, Fegade B, Bhaskar VH (2015) GC-MS analysis of phytoconstituents in alcohol extract of Epiphyllum oxypetalum leaves. J Pharmaco and Phytochem 4(1):149-154. Direct link

Dhawan D, Gupta J (2017) Comparison of Different Solvents for Phytochemical Extraction Potential from Datura metel Plant Leaves. Int J Biol Chem 11:17-22. https://doi.org/10.3923/ijbc.2017.17.22

Dieme C, Bechah Y, Socolovschi C, Audoly G, Berenger JM, Faye O, Raoult D, Parola P (2015) Transmission potential of Rickettsia felis infection by Anopheles gambiae mosquitoes. Proc Nat Acad Sci 112:80888093. https://doi.org/10.1073/pnas.1413835112

Dinesh D, Murugan K, Madhiyazhagan P, Panneerselvam C, Kumar PM, Nicoletti M, Jiang W, Benelli G, Chandramohan B, Suresh U (2015) Mosquitocidal and antibacterial activity of green-synthesized silver nanoparticles from Aloe vera extracts: towards an effective tool against the malaria vector Anopheles stephensi?. Parasitol Res 114(4):1519-1529. https://doi.org/10.1007/s00436-015-4336-Z

Dinesh MG, Subbarayan R, Rallapalli S, Kansrajh C, Kalaivani R (2014) Terminalia bellerica leaf extracts induce apoptosis in Hep G2 cells and regulates cell cycle progRes sion by inducing G2/M cell cycle arrest t. Indian J Res Pharma and Biotechn 2(1):1044. Direct link

Duke JA (2000) Dr Duke's Phytochemical and Ethnobotanical databases, Phytochemical database.- USDAARSNGRL, Beltsville Agricultural Research Centre, Maryland, USA. Direct link 
562

563

564

565

566

567

568

569

570

571

572

573

574

575

576

577

578

579

580

581

582

583

584

585

586

587

588

589

590

591

592

593

594

595

596

597

598

599

600

601

Ebenezer O, Jordaan M, Damoyi N, Shapi M (2020) Discovery of Potential Inhibitors for RNA-Dependent RNA Polymerase of Norovirus: Virtual Screening, and Molecular Dynamics. Int J Molecul Sci 22(171):1-24. https://doi.org/10.3390/ijms22010171

European Commission (2021) Pesticides/Sustainable Use of Pesticides/Integrated Pest Management (IPM). Available online: https://ec.europa.eu/food/plant/pesticides/sustainable_use pesticides/ipm_en

Finney DJ (1971) Probit analysis. Cambridge University, London pp.68-78. https://doi.org/10.1002/bimj.19720140111

Fradin MS, Day JF (2002) Comparative efficacy of insect repellents against mosquito bites. New England J Med 347(1):13-18. https://doi.org/10.1056/NEJMoa011699

Gaddaguti V, Jwala Mounika S, Sowjanya K, Rao T, Krishna Chakravarthy MSR, Allu Prasada Rao R (2012) GCMS analysis and in silico molecular docking studies of mosquito repellent compounds from Hyptis suaveolens. Int J Bioass 01(09):36-41. Direct link

Gangola S, Khati P, Bhatt P, Sharma P (2017) India as the heritage of medicinal plant and their Use. Curr Tren Biomed Eng Biosci 4(4):001-002. https://doi.org/10.19080/CTBEB.2017.04.555641

Goodyer L, Behrens RH (1998) The safety and toxicity of insect repellents. American J Trop Med and Hyg 59:323-324. https://doi.org/10.4269/ajtmh.1998.59.323

Govindarajan M, Karuppannan P (2011) Mosquito larvicidal and ovicidal properties of Eclipta alba (L.) Hassk (Asteraceae) against chikungunya vector, Aedes aegypti (Linn.) (Diptera: Culicidae). Asian Pac J Trop Med 4(1):24-28. https://doi.org/10.1016/S1995-7645(11)60026-6

Halperin I, Ma B, Wolfson H, Nussinov R (2002) Principles of docking: An overview of search algorithms and a guide to scoring functions. Prot 47:409-443. https://doi.org/10.1002/prot.10115.

Harborne JB (1973) Phytochemical Methods. Chapman and hall Ltd., London: U.K., pp.49-188. http://www.thomson.com

Hassan MI, Hammad KM, Saeed SM (2015) Repellent Effect of Ocimum Basilicum and Glycyrrhiza Glabra Extracts against the Mosquito Vector, Culex Pipiens (Diptera: Culicidae). J Egyptian Soci Parasitol 240 (2457):1-8. https://doi.org/10.12816/0017569

Hooda V, Sharma G, Singla R (2011) Smilax Zeylanica Linn. A natural therapeutic hub. Pharmacol 2:151-154. Direct link

Isaacs AT, Mawejje HD, Daniel ST, Donnelly RMJ (2018) Genome-wide transcriptional analyses in Anopheles mosquitoes reveals an unexpected association between salivary gland gene expression and insecticide Resistance. BMC Genom 19:225. https://doi.org/10.1186/s12864-018-4605-1

Isaiah S, Arun Kumar C, Senthamizh Selvan N (2016) Phytochemical screening, antimicrobial activity and GC-MS analysis of Corchorus tridens L. IJPR 6(12):353. https://doi.org/10.7439/ijpr.v6i12.3736

Jegadeeswari P, Nishanthini A, Muthukumarasamy S, Mohan VR (2012) GC-MS analysis of bioactive components of Aristolochia krysagathra (Aristolochiaceae). J Curr Chem Pharm Sci 2(4):226-232. Direct $\underline{\text { link }}$

Kalaichelvi K, Dhivya SM (2017) Screening of phytoconstituents, UV-VIS Spectrum and FTIR analysis of Micrococca mercurialis (L.). Benth. Int J Herbal Med 5(6):40-44. Direct link

Kamhawi S, Aslan H, Valenzuela JG (2014) Vector saliva in vaccines for visceral leishmaniasis: a brief encounter of high consequence?. Fron Pub Healt 2:1-6. https://doi.org/10.3389/fpubh.2014.00099 
602

603

604

605

606

607

608

609

610

611

612

613

614

615

616

617

618

619

620

621

622

623

624

625

626

627

628

629

630

631

632

633

634

635

636

637

638

639

640

Karthik Prabu M, Samydurai P, Subbaiyan B, Thangapandian V (2013) Phytochemical constituents and gas chromatography-mass spectrometry analysis of Caralluma diffusa (wight) aerial part. Int J Pharma and Pharmace Sci 5(3):602-605. Direct link

Kitchen DB, Decornez H, Furr JR, Bajorath J (2004) Docking and scoring in virtual screening for drug discovery: Methods and applications. Nat Rev Drug Dis 3:935-948. https://doi.org/10.1038/nrd1549

Kolb P, Ferreira RS, Irwin JJ, Bshoichet BK (2009) Docking and chemo informatics screens for new ligands and targets. Curr Opin Biotech 20:429-436. https://doi.org/10.1016/j.copbio.2009.08.003

Kumaravel S, Muthukumaran P, Shanmugapriya K (2017) Chemical composition of Trigonella foenumg raecum through gas chromatography mass spectrometry analysis. J Med Plants Studies 5(3):1-3. Direct $\underline{\text { link }}$

Matasyoh JC, Dittrich B, Schueffler A, Laatsch H (2011) Larvicidal activity of metabolites from the endophytic Podospora sp. against the malaria vector Anopheles gambiae. Parasitol Res 108(3):561-566. https://doi.org/10.1007/s00436-010-2098-1

Mohammed GJ, Kadhim MJ, Hussein HM (2016) Characterization of bioactive chemical compounds from Aspergillus terreus and evaluation of antibacterial and antifungal activity. Int $\mathrm{J}$ Pharmac and Phytochem Res 8(6):889-905. Direct link

Muegge I., Rarey M., 2001. Small molecule docking and scoring. Reviews in Computational Chemistry, 17: 160. https://doi.org/10.1002/0471224413.ch1

Murali A, Ashok P, Madhavan V (2012) Screening of methanol extract of roots and rhizomes of Smilax zeylanica $\mathrm{L}$ for hepatoprotective effect against carbontetrachloride induced hepatic damage. J Exp Integ Med 2(3):237-244. https://doi.org/0.5455/jeim.050512.or.028

Murugan K, Benelli G, Ayyappan S, Dinesh D, Panneerselvam C, Nicoletti M, Hwang JS, Kumar M, Subramaniam J, Suresh U (2015) Toxicity of seaweed-synthesized silver nanoparticles against the filariasis vector Culex quinquefasciatus and its impact on predation efficiency of the cyclopoid crustacean Mesocyclops longisetus. Parasitol Res 114 (6): 2243 - 2253. https://doi.org/10.1007/s00436-015-4417-Z

Murugan K, Kumar PM, Kovendan K, Amerasan D, Subrmaniam J, Hwang JS (2012) Larvicidal, pupicidal, repellent and adulticidal activity of Citrus sinensis orange peel extract against Anopheles stephensi, Aedes aegypti and Culex quinquefasciatus (Diptera: Culicidae). Parasitol Res 111(4):1757-1769. https://doi.org/10.1007/s00436-012-3021-8

Norris E, Coats J (2017) Current and future repellent technologies: The potential of spatial repellents and their place in mosquito-borne disease control. Int $\mathbf{J}$ Environ Res and public health 14(2):124. https://doi.org/10.3390/ijerph14020124

Ogbuewu IP (2008) Physiological responses of rabbits fed graded levels of neem (Azadirachta indica) leaf $\begin{array}{llll}\text { meal. Federal } \quad \text { University } & \text { Owerri, }\end{array}$ http://futoportal.silveredgeprojects.com/Research/FUTO/201.pdf

Padma M, Ganesan S, Jayaseelan T, Azhagu Madhavan S, Sasikala P, Senthilkumar S, Mani P (2019) Phytochemical screening and GC-MS analysis of bioactive compounds present in ethanolic leaves extract of Silybum marianum (L). J Drug Deliv Therap 9(1):85-89. https://doi.org/10.22270/jddt.v9i1.2174 
Pandey BP, Thapa R, Upreti A (2017) Chemical composition, antioxidant and antibacterial activities of essential oil and methanol extract of Artemisia vulgaris and Gaultheria fragrantissima collected from Nepal. Asian Pac J trop med 10(10):952-959. https://doi.org/10.1016/j.apjtm.2017.09.005

Parola P, Musso D, Raoult D (2016) Rickettsia felis: the next mosquito-borne outbreak?. Lan Inf Dis 16:11121113. https://doi.org/10.1016/S1473-3099(16)30331-0

Parthipan B, Suky MGT, Mohan VR (2015) GC-MS analysis of phytocomponents in Pleiospermium alatum (Wall. ex Wight \&Arn.) Swingle, (Rutaceae). J Pharmaco and Phytochem 4(1):216-222. Direct link

Pingen M, Schmid MA, Harris E, Mckimmie CS (2017) Mosquito Biting Modulates Skin Response to Virus Infection. Tren Parasit 33:645-657. https://doi.org/10.1016/j.pt.2017.04.003

Rajesh V, Perumal P (2014) In-vitro cytoprotective activity of Smilax zeylanica leaves against hydrogen peroxide induced oxidative stress in L-132 and BRL 3A cells. Orient Pharm Exp Med 14(3):255-268. https://doi.org/10.1007/s13596-014-0154-6

Rawani A, Ghosh A, Chandra G (2010) Mosquito larvicidal activities of Solanum nigrum L. leaf extract against Culex quinquefasciatus Say. Parasitol Res 107(5):1235-1240. . https://doi.org/10.1007/s00436-010$\underline{1993-9}$

Reed SG, Coler RN, Mondal D, Kamhawi S, Valenzuela JG (2016) Leishmania vaccine development: exploiting the host-vector-parasite interface. Exp Rev Vacc 15:81-90. https://doi.org/10.1586/14760584.2016.1105135.

Sahoo SS, Shukla S, Nandy S, Sahoo HB (2012) Synthesis of novel coumarin derivatives and its biological evaluations. European J Experimen Bio 2(4):899-908. Google Scholar

Saikia D, Parihar S, Chanda D, Ojha S, Kumar JK Chanotiya CS Shanker K Negi AS (2010) Antitubercular potential of some semisynthetic analogues of phytol. Bioorga and med chem letters 20(2):508-512. https://doi.org/10.1016/j.bmcl.2009.11.107

Sermakkani M, Thangapandian V (2012) GC-MS analysis of Cassia italica leaf methanol extract. Asian J Pharm Clin Res 5(2):90-94. Google Scholar

Shahina P, Shahzad A, Upadhyaya P, Yadav V (2016) Gas chromatography-mass spectrometry analysis of methanolic leaf extract of Cassia angustifolia Vahl. Asian J Pharm Clin Res 9:111-116. https://doi.org/10.22159/ajpcr.2016.v9s3.14512

Shibula K, Velavan S (2015) Determination of phytocomponents in methanolic extract of Annona muricata leaf using GC-MS technique. Int J Pharmac Phytochem Res 7(6): 1251-1255. Direct link

Shoichet BK, Mc Govern SL, Wei B, Irwin JJ (2002) Lead discovery using molecular docking. Curr Opin Chel Biol 6:439- 446. https://doi.org/10.1016/s1367-5931(02)00339-3

Singh H, Singh OP, Akhtar N, Sharma G, Sindhania A, Gupta N, Valecha N (2018) First report on the transmission of Zika virus by Aedes (Stegomyia) aegypti (L.) (Diptera: Culicidae) during the 2018 Zika outbreak in India. Acta Trop 199:105114. https://doi.org/10.1016/j.actatropica.2019.105114

Sofowara A (1993) Medicinal plants and traditional medicine in Africa. Spectrum Books Ltd., Ibadan: Nigeria. pp.289-300.

Soosairaj S, Dons T (2016) Bio-active compounds analysis and characterization in ethanolic plant extracts of Justicia tranquebariensis L. (Acanthaceae)-using GC-MS. Int J Chem Tech Res 9:260-265. Direct link

Sousa S.F., Fernandes P.A., Ramos M.J., 2006. Protein-ligand docking: Current status and future challenges. Proteins, 65: 15-26. https://doi.org/10.1002/prot.21082. 
682

683

684

685

686

687

688

689

690

691

692

693

694

695

696

697

698

699

700

701

702

703

704

705

706

707

708

709

710

711

712

713

714

715

716

717

718

719

720

721

722

Spero CN, Gonzalez IY, Scialdone AM, Hallahan LD (2008) Repellency of hydrogenated catmint oil formulations to black flies and mosquitoes in the field. $\mathrm{J}$ Med Entomo 45:1080-1086. https://doi.org/10.1603/0022-2585

Sritabutra D, Soonwera M (2013) Repellent activity of herbal essential oils against Aedes aegypti (Linn.) and Culex quinquefasciatus (Say.). Asian Pac J Trop Dis 3(4):271-276. https://doi.org/10.1016/S2222$\underline{1808(13) 60069-9}$

Srivastava R, Mukerjee A, Verma A (2015) GC-MS analysis of phytocomponents in, pet ether fraction of Wrightia tinctoria seed. Pharmaco J, 7(4). https://doi.org/10.5530/pj.2015.4.7

Starlin T, Arul RC, Ragavendran P, Gopalakrishnan VK (2012) Phytochemical screening, functional groups and element analysis of Tylophorapauci flora wight and arn. Int Res J Pharm 3(6):180-183. Academia link

Suresh U, Murugan K, Benelli G, Nicoletti M, Barnard DR, Panneerselvam C, Kumar PM, Subramaniam J, Dinesh D, Chandramohan B (2015) Tackling the growing threat of dengue: Phyllanthus nirurimediated synthesis of silver nanoparticles and their mosquitocidal properties against the dengue vector Aedes aegypti (Diptera: Culicidae). Parasitol Res, 114(4): https://doi.org/1551-1562. 10.1007/s00436$\underline{015-4339-9}$

Tchoumbou MA, Mayi MPA, Malange ENF, Foncha FD, Kowo C, Fru-Cho J, Kowo C, Fru-Cho J, Tchuinkam T, Awah-Ndukum J, Dorazio R, Anong DN, Cornel AJ, Sehgal RNM (2020) Effect of deforestation on prevalence of avian haemosporidian parasites and mosquito abundance in a tropical rainforest of Cameroon. Int J Parasit 50:63-73. https://doi.org/10.1016/j.ijpara.2019.10.006

Thireou T, Kythreoti G, Tsitsanou KE, Koussis K, Drakou CE, Kinnersley J, Kröber T, Guerin PM, Zhou JJ, Iatrou K, Eliopoulos E (2018) Identification of novel bioinspired synthetic mosquito repellents by combined ligand-based screening and OBP-structure-based molecular docking. Ins Biochem Molecul Biol 98:48-61. https://doi.org/10.1016/j.ibmb.2018.05.001

USDA (2021) Office of the Chief Economist/Pest Management/Integrated Pest Management.- Available online: https://www.usda.gov/oce/pest/integrated-pest-management (accessed on 4 January 2021).

Van Den Dool H, Kratz PD (1963) A generalization of the retention index system including linear temperature programmed gas liquid partition chromatography. J Chromatograp A 11:463-471. https://doi.org/10.1016/s0021-9673(01)80947-x

WHO (1981) Instructions for determining the susceptibility or resistance of mosquito larvae to insecticides. https://apps.who.int/iris/handle/10665/69615

WHO (2020b) Fact sheets. Sources: https://www.who.int/news-room/fact-sheets/detail/vector-borne-diseases

World Health Organization (2020a) Evaluation of genetically modified mosquitoes for the control of vectorborne diseases. Geneva: World Health Organization p. 1-7. Source: https://www.who.int/publications/i/item/9789240013155

7

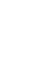


Molecular interaction of Novel Phytocompounds from Smilax zeylanica $(\mathrm{L})$ against the targeted protein of mosquito vectors and their potential activity

Description:

GC/MS Method: GC: METHOD-1.mth MS: METHOD-1.EXP Sample ID:
Page 1 of 1

Vial Number: 23

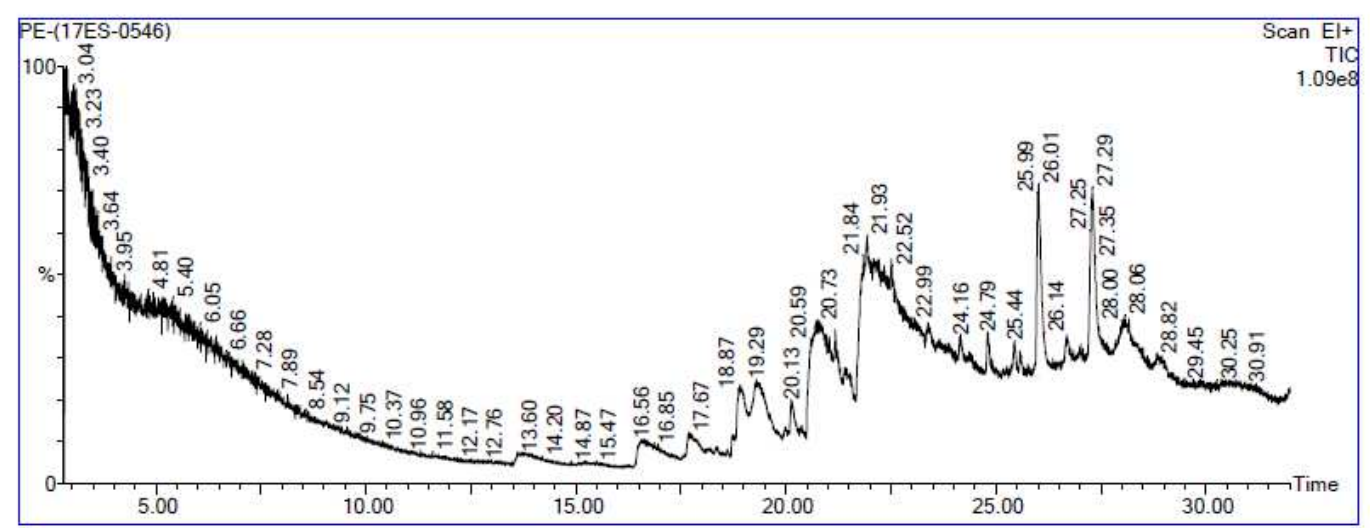

732

Fig. 1: GC-MS chromatogram of the petroleum ether leaf extract of Smilax zeylanica

733

734

735

736

737

738

739

740

741

742

743

744 
Description:

GC/MS Method: GC: METHOD-1.mth MS: METHOD-1.EXP Sample ID: $\quad$ ACE-(17ES-0547)
Page 1 of 1

Vial Number: 24

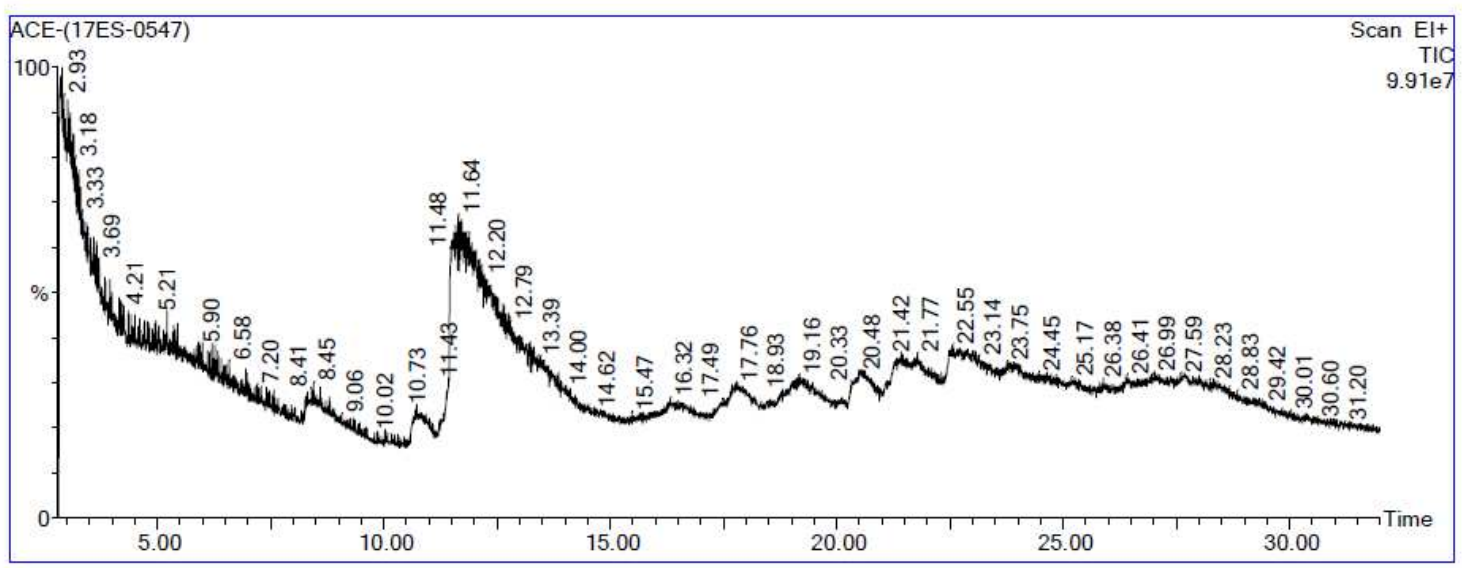

749

Fig. 2: GC-MS chromatogram of the acetone leaf extract of Smilax zeylanica

750

751

752

753

754

755

756

757

758

759

760

761

762

763

764

765 
Description:

GC/MS Method: GC: METHOD-1.mth MS: METHOD-1.EXP ET-(17ES-0548)

Page 1 of 1

Vial Number: 25

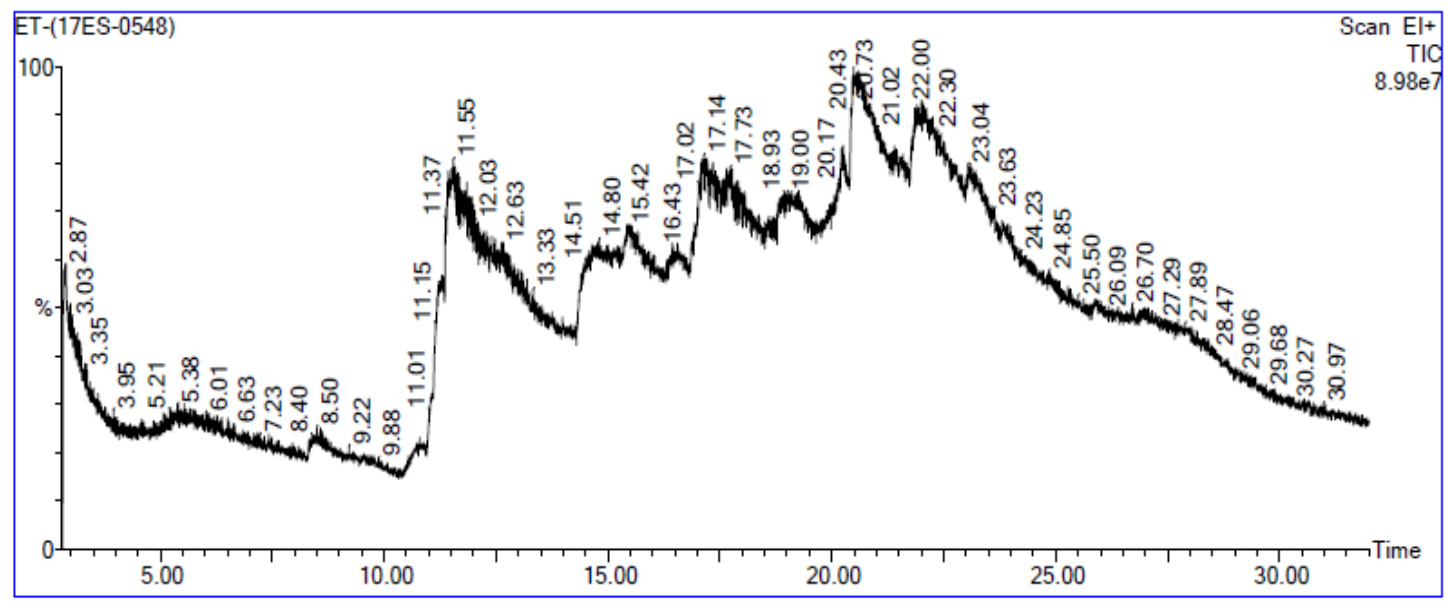

767

Fig. 3: GC-MS chromatogram of the ethanol leaf extract of Smilax zeylanica 


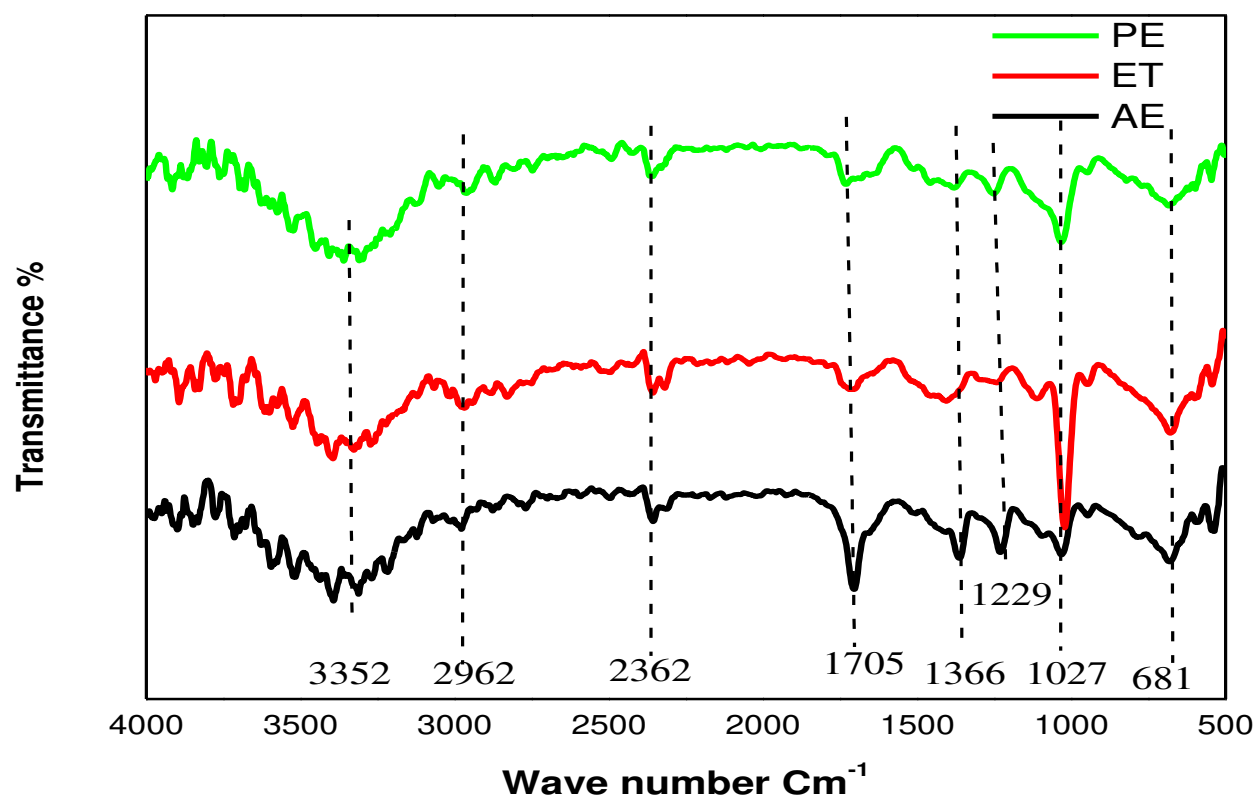

786

Fig. 4: FTIR analysis leaf extract of Smilax zeylanica 
804

805
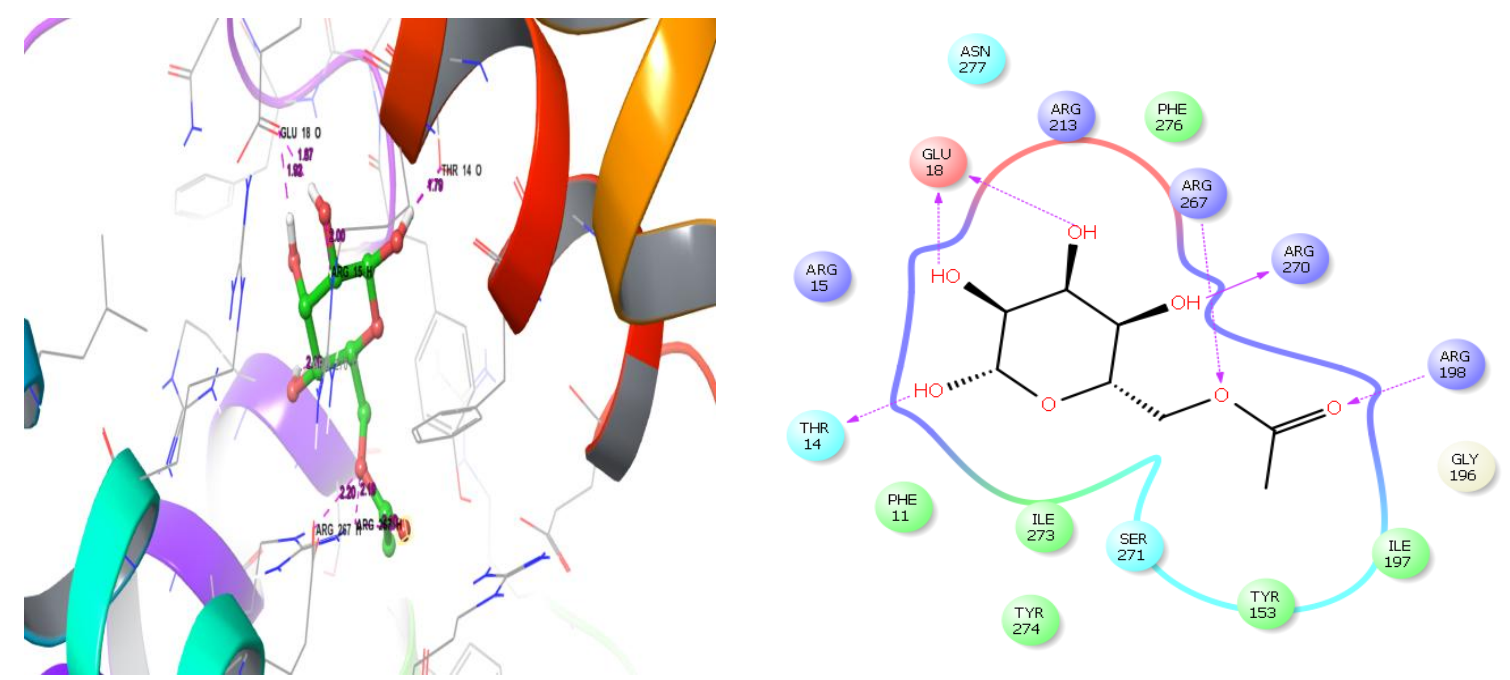

806

Fig. 5: Docked Complex of 6-Acetyl-.Beta.-D-Mannose with Aedes aegypti and 807 Culex quinquefasciatus D7 protein (PDB ID : 3DXL)

808

809

810

811

812

813

814

815

816

817

818

819

820

821

822 

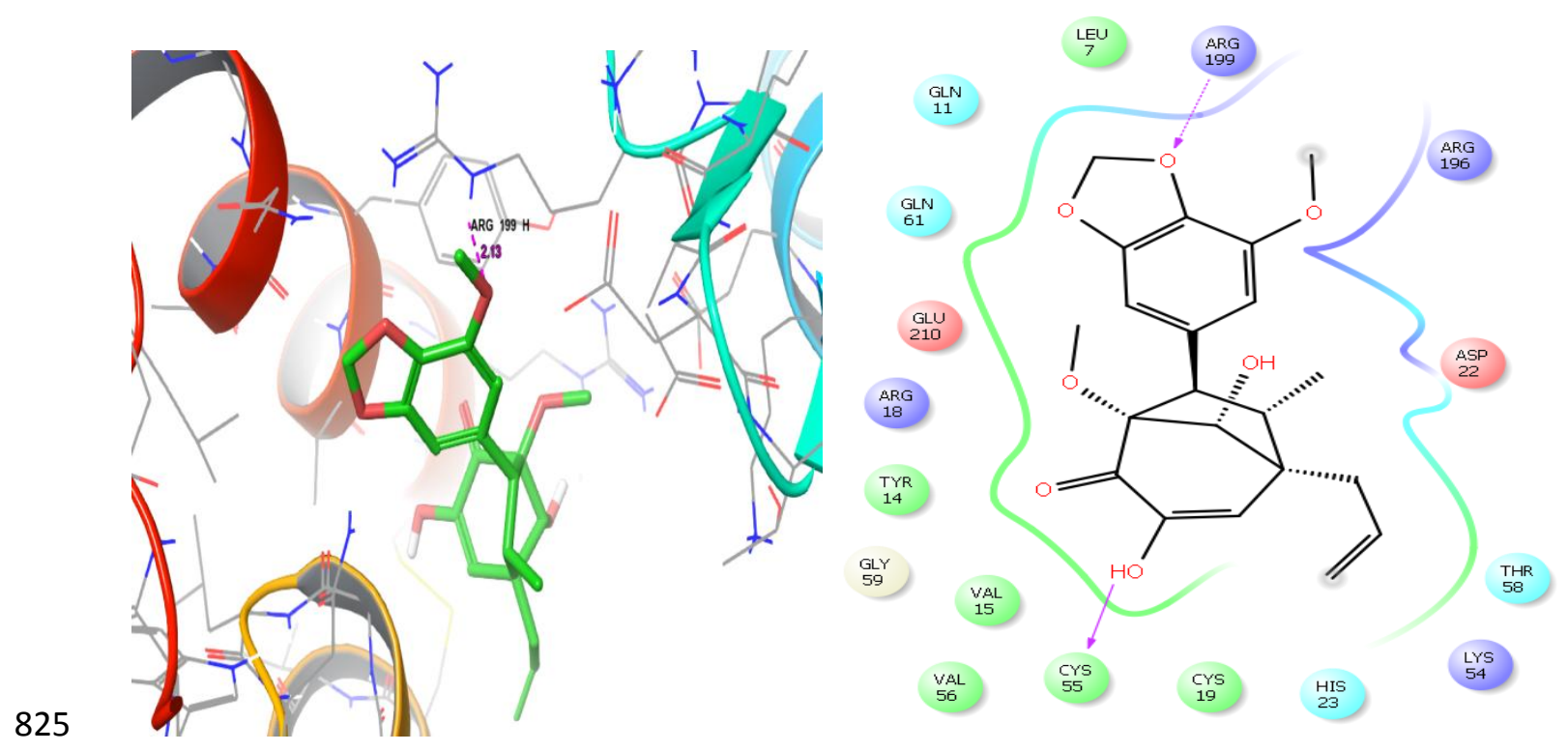

826

Fig. 6: Docked Complex of Bicyclo[3.2.1]oct-3-en-2-one, 3,8-Dihydroxy-1-Methoxy-7-(7-

827 Methoxy-1,3 with Anopheles stephensi D7 protein (PDB ID : 3NGV)

835

836

837

838

839

840

841

842 

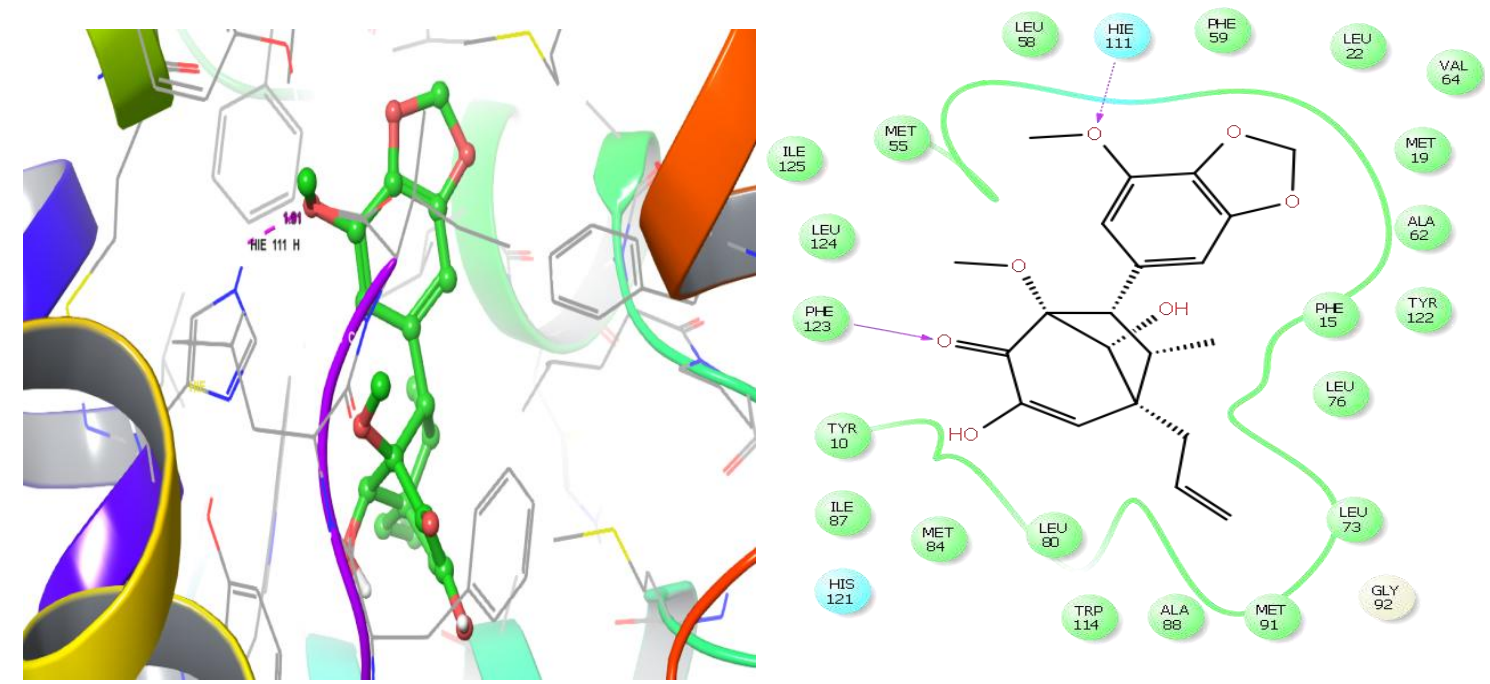

845

Fig. 7: Docked Complex of Bicyclo [3.2.1] oct-3-en-2-one, 3,8-Dihydroxy-1-Methoxy-7-(7-

846

Methoxy-1,3 with Aedes aegypti Odorant protein (PDB ID : 3K1E)

847

848

849

850

851

852

853

854

855

856

857

858

859

860

861

862 

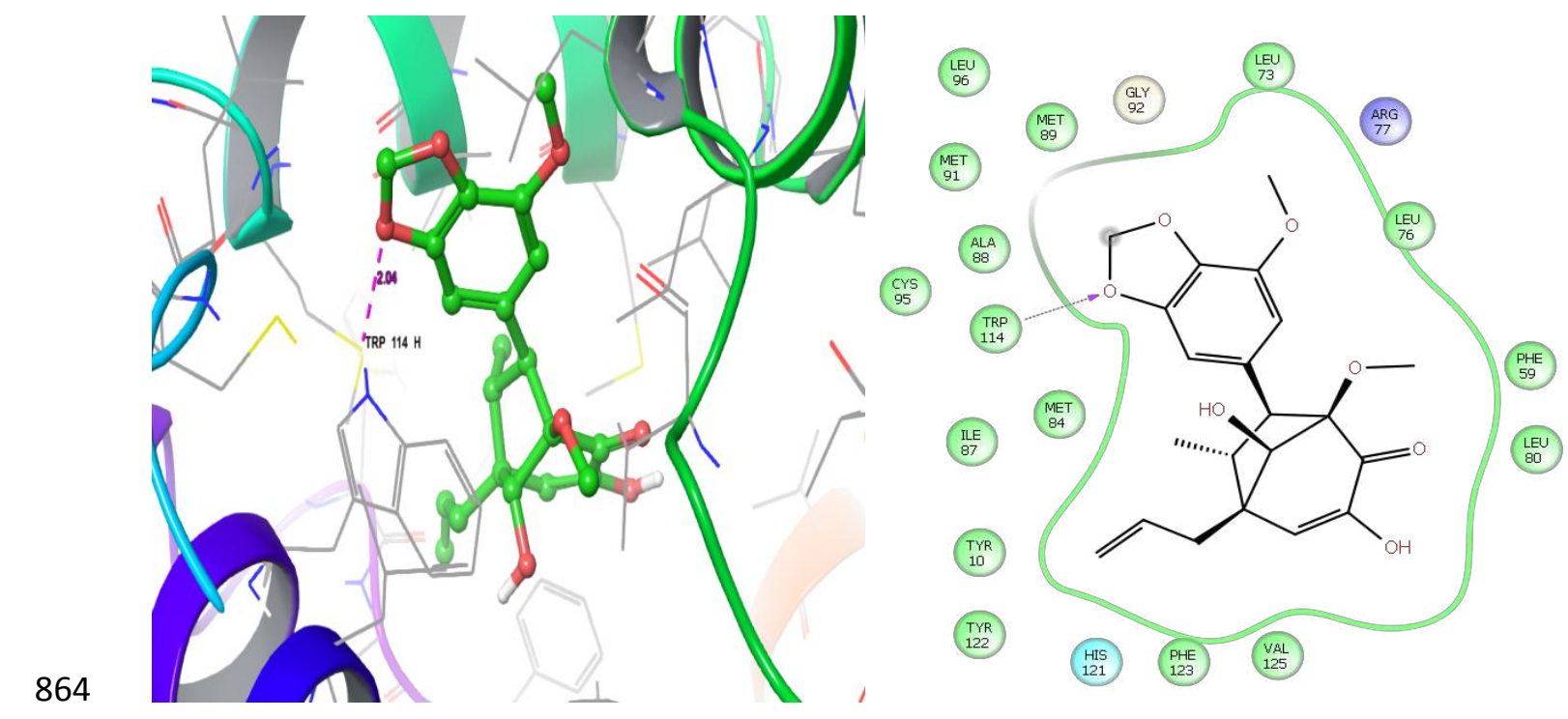

865

Fig. 8: Docked Complex of Bicyclo[3.2.1]oct-3-en-2-one, 3,8-Dihydroxy-1-Methoxy-7-(7-

866

Methoxy-1,3 with Culex quinquefasciatus Odorant protein (PDB ID : 2L2C)

867

868

869

870

871

872

873

874

875

876

877 


\section{TABLES}

879 Table 1: Preliminary phytochemical tests for plant extracts

\begin{tabular}{|c|c|c|}
\hline Phytoconstituents & Test & Observation \\
\hline Tannins (Braymer's Test) & $2 \mathrm{ml}$ extract $+2 \mathrm{ml} \mathrm{H}_{2} \mathrm{O}+2-3$ drops $\mathrm{FeCl}_{3}(5 \%)$ & Green precipitate \\
\hline Terpenoids & $\begin{array}{l}2 \mathrm{ml} \mathrm{extract}+2 \mathrm{ml}\left(\mathrm{CH}_{3} \mathrm{CO}\right)_{2} \mathrm{O}+2-3 \text { drops conc. } \\
\mathrm{H} 2 \mathrm{SO}_{4}\end{array}$ & Deep red coloration \\
\hline Flavonoids & $1 \mathrm{ml} \mathrm{extract}+1 \mathrm{ml} \mathrm{Pb}(\mathrm{OAc})_{4}(10 \%)$ & Yellow coloration \\
\hline Alkaloids (Hager’s Test) & $2 \mathrm{ml}$ extract + few drops of Hager's reagent & Yellow precipitate \\
\hline Phenolic & $2 \mathrm{ml} \mathrm{extract}+2 \mathrm{ml} \mathrm{H}_{2} \mathrm{O}+0.5 \mathrm{ml}$ of $\mathrm{FeCl}_{3}(\mathrm{w} / \mathrm{v})$ & formation of an intense colour \\
\hline Steroids (Salkowski Test) & $\left(2 \mathrm{ml} \mathrm{extract}+2 \mathrm{ml} \mathrm{CHCl}{ }_{3}+2 \mathrm{ml} \mathrm{H}_{2} \mathrm{SO}_{4}\right.$ (conc.) & Reddish brown ring at the junction \\
\hline
\end{tabular}

880 
Table 2: The primary phytochemicals screening leaf extract of Smilax zeylanica

\begin{tabular}{|c|l|c|c|}
\hline SI.No. & \multicolumn{1}{|c|}{ Phytochemical } & P. ether & Ecthanol \\
\hline 1 & Tannins & - & + \\
\hline 2 & Terpenoids & + & + \\
\hline 3 & Flavonoids & - & + \\
\hline 4 & Alkaloids & + \\
\hline 5 & Phenolic & + \\
\hline 6 & Steroids & + \\
\hline
\end{tabular}


Table 3: GC-MS profiles revealed the phytochemical compoundspresence in the petroleum ether leaf extract of Smilax zeylanica

\begin{tabular}{|c|c|c|c|c|c|c|c|}
\hline $\begin{array}{l}\text { Sl. } \\
\text { No }\end{array}$ & RT & Name of the compounds & Structure and MF & MW & $\begin{array}{c}\text { Area } \\
(\%)\end{array}$ & For & $\operatorname{Rev}$ \\
\hline 1 & 18.910 & Phytol & $\mathrm{C}_{20} \mathrm{H}_{40} \mathrm{O}$ & 296 & 2.426 & 880 & 936 \\
\hline 2 & 19.295 & $\begin{array}{c}\text { 3,7,11,15-Tetramethyl-2- } \\
\text { Hexadecen-1-ol }\end{array}$ & $\mathrm{C}_{20} \mathrm{H}_{40} \mathrm{O}$ & 296 & 4.375 & 789 & 894 \\
\hline 3 & $\begin{array}{l}20.776 \\
21.026\end{array}$ & N-Hexadecanoic Acid & $\mathrm{C}_{16} \mathrm{H}$ & 256 & $10.985,1.983$ & $\begin{array}{l}860 \\
826\end{array}$ & 934,915 \\
\hline 4 & $\begin{array}{c}21.171, \\
21.426, \\
21.926\end{array}$ & Pentadecanoic Acid & $\mathrm{C}_{15} \mathrm{H}_{30} \mathrm{O}_{2}$ & 242 & $\begin{array}{l}3.574 \\
3.030 \\
24.734\end{array}$ & $\begin{array}{l}838, \\
822, \\
891\end{array}$ & $\begin{array}{l}896, \\
902, \\
932\end{array}$ \\
\hline 5 & $\begin{array}{l}22.506 \\
23.382\end{array}$ & $\begin{array}{c}\text { 1-Hexyl-2- } \\
\text { Nitrocyclohexane }\end{array}$ & $\mathbf{C}_{12} \mathrm{H}_{23}$ & 213 & $17.997,8.629$ & 483,449 & 873,846 \\
\hline 6 & 24.157 & E-3-Pentadecen-2-ol & & 226 & 4.318 & 626 & 866 \\
\hline 7 & 24.792 & Hexadecane, 1-Chloro- & $\mathrm{C}_{16} \mathrm{H}_{33} \mathrm{Cl}$ & 260 & 1.623 & 555 & 857 \\
\hline 8 & 26.013 & Tritetracontane & $\mathbf{C}_{43} \mathbf{H}_{88}$ & 604 & 5.017 & 801 & 941 \\
\hline 9 & 27.288 & Heptacosane, 1-Chloro- & $\mathrm{C}_{27} \mathrm{H}_{55} \mathrm{Cl}$ & 414 & 6.869 & 768 & 919 \\
\hline 10 & 28.063 & Vitamin E & - 101. & 430 & 4.442 & 435 & 653 \\
\hline
\end{tabular}

RT- Retention time; P- Probability; MF- Molecular formula; MW- Molecular weight; For- Forward; Rev- Reverse. 
Table 4: GC-MS profiles revealed the phytochemical compounds presence in the acetone leaf extract of Smilax zeylanica

\begin{tabular}{|c|c|c|c|c|c|c|c|}
\hline $\begin{array}{l}\text { Sl. } \\
\text { No }\end{array}$ & RT & Name of the compounds & MF & MW & $\begin{array}{c}\text { Area } \\
(\%)\end{array}$ & For & $\operatorname{Rev}$ \\
\hline 1 & $\begin{array}{l}11.582, \\
11.637, \\
11.822\end{array}$ & 2-(2-Piperidin-1-yl-Ethyl)-Pyridine & +2 & 191 & $\begin{array}{l}16.148, \\
15.996, \\
28.687\end{array}$ & $\begin{array}{c}358, \\
367, \\
359\end{array}$ & $\begin{array}{l}854, \\
839, \\
845\end{array}$ \\
\hline 2 & 20.535 & 3-Acetoxydodecane & $\mathrm{C}_{14} \mathrm{H}_{28}$ & 228 & 7.133 & 489 & 706 \\
\hline 3 & 22.546 & N-Hexadecanoic Acid & $\mathrm{C}_{16} \mathrm{H}_{32}$ & 256 & 6.572 & 468 & 770 \\
\hline 4 & 22.891 & Hexadecanoic Acid, 2-Bromo- & $\mathrm{C}_{16} \mathrm{H}_{31} \mathrm{O}_{2} \mathrm{Br}$ & 334 & 9.040 & 355 & 675 \\
\hline
\end{tabular}




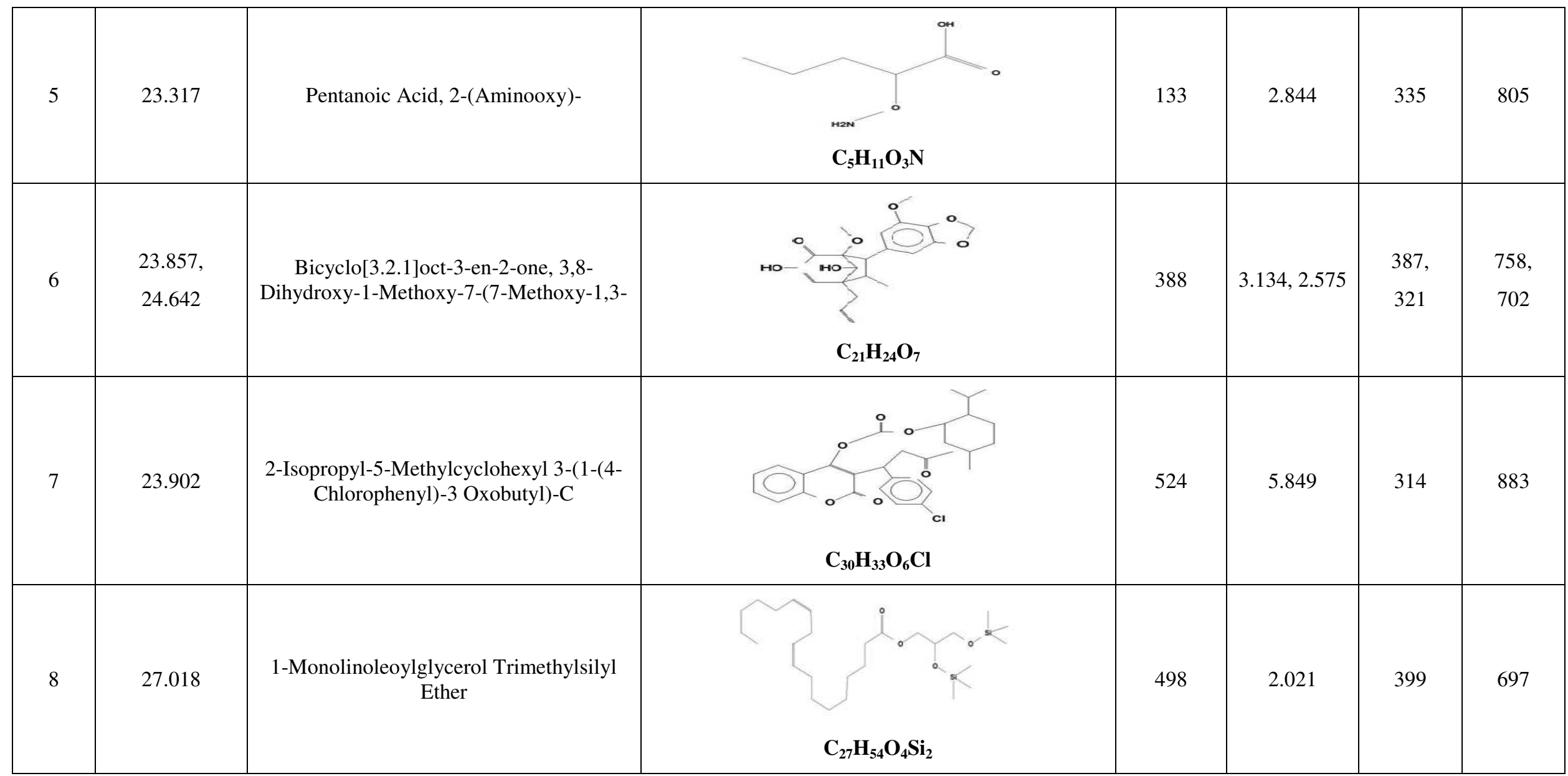

RT- Retention time; MF- Molecular formula; MW- Molecular weight; For- Forward; Rev- Reverse. 
Table 5: GC-MS profiles revealed the phytochemical compounds presence in the ethanol leaf extract of Smilax zeylanica

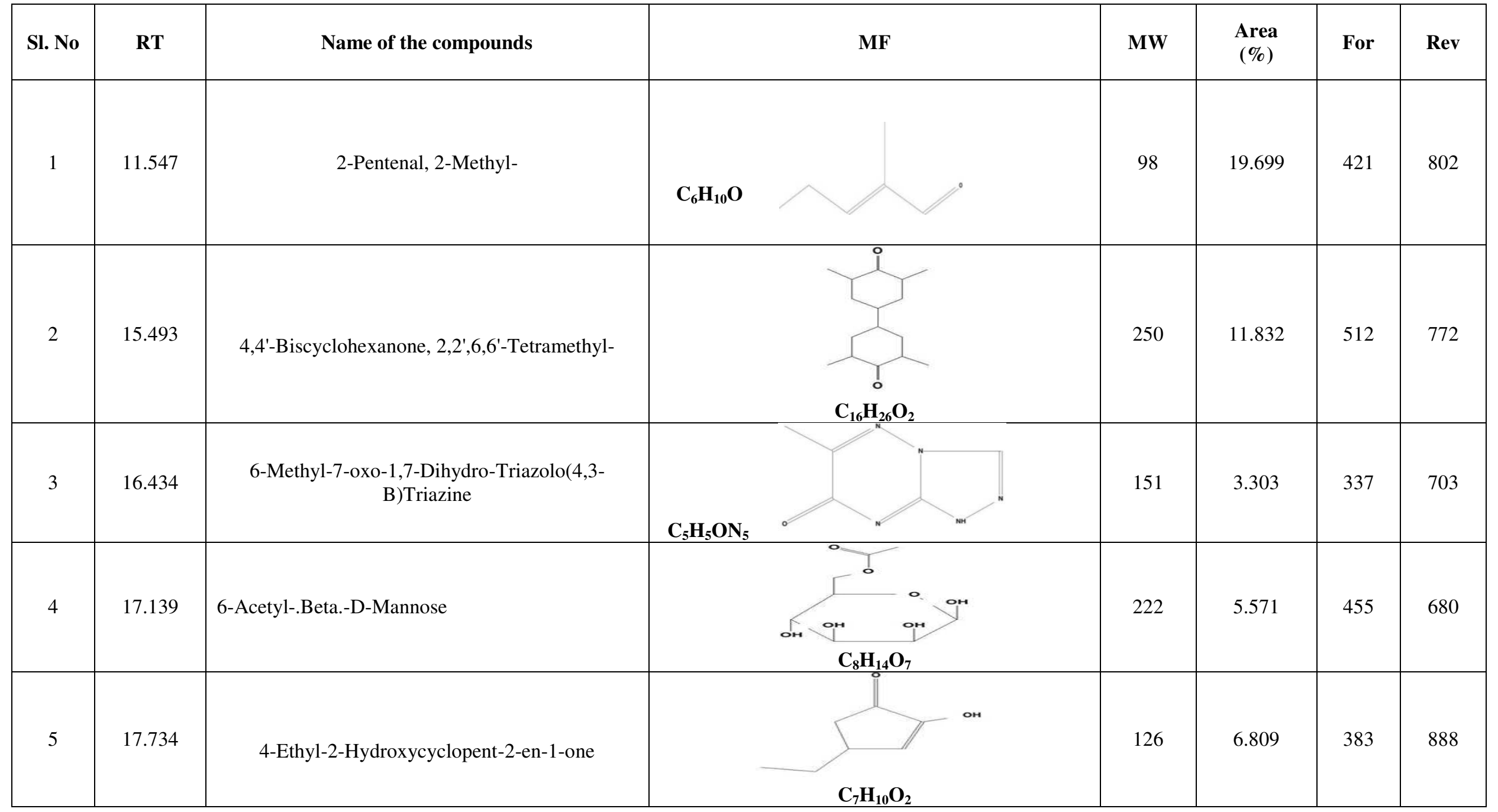




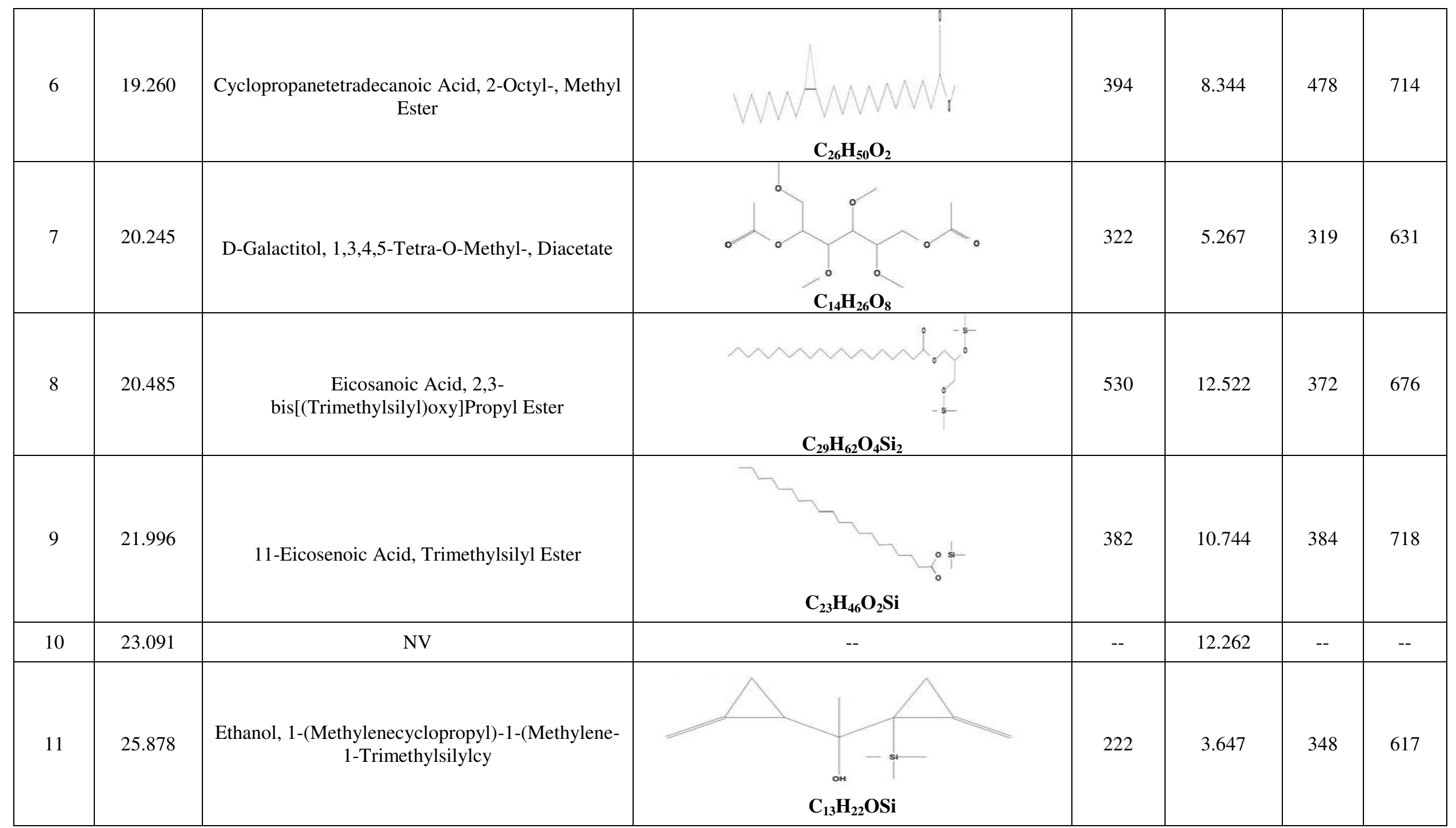

RT- Retention time; NV- Not validated; MF- Molecular formula; MW- Molecular weight; For- Forward; Rev- Reverse. 
Table 6: GC-MS analysis showed the phytochemical compounds presence in the leaf extract of Smilax zeylanica and their biological activities

\begin{tabular}{|c|c|c|c|}
\hline S. No & Name of the compounds & Biological properties & References \\
\hline 1. & Phytol & $\begin{array}{l}\text { Mycobacteria, anticonvulsant, antispasmodic, anticancer } \\
\text { activities, Precursor for manufacture of Vitamin E, antimicrobial, } \\
\text { anti-diuretic, anti-inflammatory, immuno stimulatory and anti- } \\
\text { diabetic activity }\end{array}$ & $\begin{array}{l}\text { (Saikia } \text { et al., 2010; } \\
\text { Costa } \text { et al., 2012; } \\
\text { Sermakkani et al., 2012) }\end{array}$ \\
\hline 2. & 3,7,11,15Tetramethyl-2-Hexadecen-1-ol & $\begin{array}{l}\text { Terpene alcohol and anti-inflammatory, antimicrobial, flavoring } \\
\text { agent, cancer-preventive, anti-diuretic, antioxidant }\end{array}$ & $\begin{array}{l}\text { (Jegadeeswari, et al., 2012; Shibula } \\
\text { et al., 2015) }\end{array}$ \\
\hline 3. & N-Hexadecanoic Acid & $\begin{array}{l}\text { Anti-inflammatory, Antioxidant, hypocholesterolemic } \\
\text { nematicide, pesticide, anti-androgenic flavor, hemolytic, 5-Alpha } \\
\text { reductase inhibitor, potent mosquito larvicide,antioxidant, } \\
\text { hypocholesterolemic, nematicide, pesticide anti-androgenic, } \\
\text { flavor, hemolytic, 5-alpha-reductase inhibitor, potent mosquito } \\
\text { larvicide }\end{array}$ & $\begin{array}{l}\text { (Dandekar et al., 2015; } \\
\text { Soosairaj and Dons 2016) }\end{array}$ \\
\hline 4. & 1-Hexyl-2-Nitrocyclohexane & Neuroactive, anti-inflammatory, analgesic Property & Dinesh et al.(2014) \\
\hline 5. & Tritetracontane & Anti-inflammatory & Isaiah et al.(2016) \\
\hline 6. & Vitamin E & $\begin{array}{l}\text { Lipid and antiaging, anti-Alzheimer, antidermatitic,antidiabetic, } \\
\text { antioxidant, antitumor, cancerpreventive,hypocholesterolemic, } \\
\text { immunostimulant, antiaging, analgesic, antidiabetic, } \\
\text { anti-inflammatory, antioxidant, antidermatitic,antileukemic, } \\
\text { antitumor, anticancer, hepatoprotective,hypocholesterolemic, } \\
\text { antiulcerogenic, vasodilator,antispasmodic, antibronchitic, } \\
\text { anticoronary }\end{array}$ & $\begin{array}{l}\text { (Shahina et al. } 2016 \text {; } \\
\text { Kumaravel et al., 2017) }\end{array}$ \\
\hline 7. & 3-Acetoxydodecane & No activity & Karthik Prabu et al.(2013) \\
\hline 8. & PentanoicAcid,2-Aminooxy)- & Antimicrobial & Duke (2000) \\
\hline 9. & $\begin{array}{l}\text { 2-Isopropyl-5-Methylcyclohexyl } \\
\text { 3-(1-(4-Chlorophenyl)-3-Oxobutyl)-Coumarin-4- }\end{array}$ & Antioxidant, antimicrobial and anti-inflammatory activity & Sahoo et al. (2012) \\
\hline
\end{tabular}




\begin{tabular}{|c|c|l|l|}
\hline & YlCarbonate & & \\
\hline 10. & $\begin{array}{c}\text { 1-Monolinoleoylglycerol } \\
\text { Trimethylsilyl Ether }\end{array}$ & $\begin{array}{l}\text { Antimicrobial, Antioxidant, Antiinflammatory, Diuretic, } \\
\text { Antiarthritic, Antiasthma }\end{array}$ & Parthipan et al.(2015) \\
\hline 11. & 6-Acetyl-Beta.-D-Mannose & Antimicrobial agents & Mohammed et al. (2016) \\
\hline 12. & 4-Ethyl-2-Hydroxycyclopent-2-en-1-one & Antibacterial activity & Ara (2012) \\
\hline 13. & $\begin{array}{c}\text { Cyclopropanetetradecanoic Acid, } \\
\text { 2-Octyl-, Methyl Ester }\end{array}$ & Antimicrobial & Srivastava et al.(2015) \\
\hline
\end{tabular}

917 Table 7: FTIR analysis of p.ether, acetone and ethanol leaf extract of Smilax zeylanica

\begin{tabular}{|c|c|c|c|}
\hline $\begin{array}{c}\text { Serial } \\
\text { number }\end{array}$ & Peak values $\mathbf{~ m}^{-\mathbf{1}}$ & Functional group vibration & Expecting chemical compound \\
\hline 1. & 3352 & Strong O-H Stretching vibration & Alcohol group \\
\hline 2. & 2962 & Medium CH vibration & Amine group \\
\hline 3. & 1707 & Strong C=O Stretching vibration & Phenol \\
\hline 4. & 1366 & Medium O-H bending vibration & Alkyl aryl ether \\
\hline 5. & 1229 & Strong C=O Stretching vibration & Alkene \\
\hline 6. & 1027 & Strong C-O Stretching vibration & C=C bending vibration \\
\hline 7. & 681 & & \\
\hline
\end{tabular}


918 Table 8: Phytochemical compounds of Smilax zeylanica extracted with petroleum ether, acetone and ethanol.

\begin{tabular}{|c|c|c|}
\hline S. No. & Compound Name & Pubchem ID \\
\hline 1. & Phytol & 5280435 \\
\hline 2. & 3,7,11,15Tetramethyl-2-Hexadecen-1-ol & 5366244 \\
\hline 3. & Pentadecanoic Acid & 13849 \\
\hline 4. & 1-Hexyl-2-Nitrocyclohexane & 544017 \\
\hline 5. & E-3-Pentadecen-2-ol & 5363322 \\
\hline 6. & Hexadecane, 1-Chloro- & 20993 \\
\hline 7. & Tritetracontane & 522398 \\
\hline 8. & Vitamin E & 14985 \\
\hline 9. & 2-(2-Piperidin-1-yl-Ethyl)-Pyridine - & 79548 \\
\hline 10. & 3-Acetoxydodecane & 537256 \\
\hline 11. & HexadecanoicAcid,2-Bromo- & 82145 \\
\hline 12. & Bicyclo[3.2.1]oct-3-en-2-one, 3,8-Dihydroxy-1-Methoxy-7-(7-Methoxy-1,3- & 101282029 \\
\hline 13. & 1-Monolinoleoylglycerol Trimethylsilyl Ether & 5377604 \\
\hline 14. & 2-Pentenal, 2-Methyl- & 5319754 \\
\hline 15. & 6-Methyl-7-oxo-1,7-Dihydro-Triazolo(4,3-B)Triazine & 592014 \\
\hline 16. & 6-Acetyl-.Beta.-D-Mannose & 439780 \\
\hline 17. & 4-Ethyl-2-Hydroxycyclopent-2-en-1-one & 566236 \\
\hline 18. & Cyclopropanetetradecanoic Acid, 2-Octyl-, Methyl Ester & 552099 \\
\hline 19. & D-Galactitol, 1,3,4,5-Tetra-O-Methyl-, Diacetate & 538739 \\
\hline 20. & Eicosanoic Acid, 2,3-bis[(Trimethylsilyl) oxy]Propyl Ester & 537899 \\
\hline 21. & 11-Eicosenoic Acid, Trimethylsilyl Ester & 5366418 \\
\hline 22. & Ethanol,1-(Methylenecyclopropyl)-1-(Methylene-1 Trimethylsilylcy & 552358 \\
\hline 23. & 4,4'-Biscyclohexanone, 2,2',6,6'-Tetramethyl- & 536293 \\
\hline
\end{tabular}


Table 9: Docking Score and H Bond interactions of potential inhibitory compounds against Aedes aegypti and

Culex quinquefasciatus D7 protein

\begin{tabular}{|c|c|c|c|l|l|}
\hline S.No & Compound Id & Glide Score & $\begin{array}{c}\text { No of H } \\
\text { Bonds }\end{array}$ & \multicolumn{1}{|c|}{ Residues } & Distance \\
\hline 1 & 439780 & -8.75 & 8 & $\begin{array}{l}\text { THR14, ARG267 } \\
\text { ARG267, ARG267 }\end{array}$ & $\begin{array}{l}\text { GLU18, GLU18, } \\
\text { ARG270, ARG15, } 1.87,2.1,2.19,2.2\end{array}$ \\
\hline 2 & 101282029 & -6.81 & 2 & ARG198, ARG57 & $2.07,1.92$ \\
\hline 3 & 538739 & -5.31 & 3 & $\begin{array}{l}\text { LYS202, ARG198, } \\
\text { ARG57 }\end{array}$ & $2.03,1.86,2.21$ \\
\hline 4 & 566236 & -5.19 & 4 & $\begin{array}{l}\text { GLU18, GLU18, ARG15, } \\
\text { ARG270 }\end{array}$ & $2.25,2.08,1.97,2.05$ \\
\hline 5 & 552358 & -4.23 & 1 & LYS202 & 2.04 \\
\hline
\end{tabular}

922

923

924

925

926

927

928

929

930

931

932

Table 10: Docking Score and $\mathrm{H}$ Bond interactions of potential inhibitory compounds against Anopheles stephensi $\mathrm{D} 7$ protein

\begin{tabular}{|c|c|c|c|c|c|}
\hline S.No & Compound Id & $\begin{array}{c}\text { Glide } \\
\text { Score }\end{array}$ & $\begin{array}{c}\text { No of H } \\
\text { Bonds }\end{array}$ & Residues & Distance \\
\hline 1 & 101282029 & -7.24 & 2 & ARG199, CYS55 & $2.13,1.97$ \\
\hline 2 & 439780 & -6.21 & 5 & $\begin{array}{c}\text { ARG199, ARG199, } \\
\text { GLN11, GLY59, GLN61 }\end{array}$ & $2.06,1.92,2.14$, \\
\hline 3 & 14985 & -5.07 & 1 & MET201 & 2.31 \\
\hline 4 & 552099 & -4.57 & 2 & ARG199, ARG199 & $1.96,2.09$ \\
\hline 5 & 536293 & -4.36 & 1 & ARG199 & 1.99 \\
\hline
\end{tabular}

Compound id- Pubchem database id, G-score - Docking score, No of H bonds - Number of H bonds involved in interaction, Residues - residues which is involved in interaction, Distance - distance of $\mathrm{H}$ bond) 
Table 11: Docking Score and H Bond interactions of potential inhibitory compounds against Aedes aegypti

Odorant protein

\begin{tabular}{|c|c|c|c|c|c|}
\hline S.No & Compound Id & $\begin{array}{c}\text { Glide } \\
\text { Score }\end{array}$ & $\begin{array}{c}\text { No of H } \\
\text { Bonds }\end{array}$ & Residues & Distance \\
\hline 1 & 101282029 & -10.89 & 1 & HIE111 & 1.91 \\
\hline 2 & 5366244 & -10.23 & 2 & HIE111, MET55 & $1.73,2.1$ \\
\hline 3 & 5280435 & -10.09 & 2 & HIE111, MET55 & $1.96,2.09$ \\
\hline 4 & 552099 & -9.73 & 1 & HIE111 & 1.99 \\
\hline 5 & 14985 & -9.36 & 1 & ARG199 \\
\hline
\end{tabular}

(Compound id- Pubchem database id, G-score - Docking score, No of H bonds - Number of H bonds involved in interaction, Residues - residues which is involved in interaction, Distance - distance of $\mathrm{H}$ bond)

Table 12: Docking Score and $\mathrm{H}$ Bond interactions of potential inhibitory compounds against Culex quinquefasciatus Odorant protein

\begin{tabular}{|c|c|c|c|c|c|}
\hline S.No & Compound Id & $\begin{array}{c}\text { Glide } \\
\text { Score }\end{array}$ & $\begin{array}{c}\text { No of H } \\
\text { Bonds }\end{array}$ & Residues & Distance \\
\hline 1 & 101282029 & -10.45 & 1 & TRP114 & 2.04 \\
\hline 2 & 14985 & -10.19 & 1 & MET201 & 1.93 \\
\hline 3 & 536293 & -8.36 & 1 & ARG199 & $1.86,1.73$ \\
\hline 4 & 5366418 & -8.12 & 1 & HIE111, MET55 & 2.09 \\
\hline 5 & 5280435 & -7.82 & 1 & HIE111 \\
\hline
\end{tabular}

941 (Compound id- Pubchem database id, G-score - Docking score, No of H bonds - Number of H bonds involved

942 in interaction, Residues - residues which is involved in interaction, Distance - distance of $\mathrm{H}$ bond) 
Table 13.Adulticidal effect of petroleum ether leaf extract of Smilax zeylanica on the malarial, dengue and filarial vectors

\begin{tabular}{|c|c|c|c|c|c|c|c|c|}
\hline \multirow{3}{*}{$\begin{array}{c}\text { Targeted } \\
\text { mosquito } \\
\text { species }\end{array}$} & \multicolumn{5}{|c|}{ Mortality (\%) (mean \pm SD) } & \multirow{3}{*}{$\begin{array}{c}\mathbf{L C}_{50} \\
\text { ppm } \\
\text { (LFL- } \\
\text { UFL) }\end{array}$} & \multirow{3}{*}{$\begin{array}{c}\text { LC }_{90} \\
\text { ppm } \\
\text { (LFL- } \\
\text { UFL) }\end{array}$} & \multirow{3}{*}{$\chi^{2}$} \\
\hline & \multicolumn{5}{|c|}{ Concentration(ppm) } & & & \\
\hline & 100 & 200 & 300 & 400 & 500 & & & \\
\hline An. stephensi & $27.0 \pm 2.23^{\mathrm{a}}$ & $39.2 \pm 1.92^{\mathrm{b}}$ & $51.6 \pm 2.07^{\mathrm{c}}$ & $66.4 \pm 1.81^{\mathrm{d}}$ & $74.7 \pm 2.22^{\mathrm{e}}$ & $\begin{array}{c}284.92 \\
(247.63- \\
320.41)\end{array}$ & $\begin{array}{c}678.15 \\
(594.86- \\
814.10)\end{array}$ & $0.220 *$ \\
\hline Ae. aegypti & $23.2 \pm 2.38^{\mathrm{a}}$ & $36.4 \pm 2.07^{b}$ & $48.6 \pm 1.92^{\mathrm{c}}$ & $62.8 \pm 2.28^{\mathrm{d}}$ & $72.0 \pm 2.54^{\mathrm{e}}$ & $\begin{array}{c}311.97 \\
(276.79- \\
348.48)\end{array}$ & $\begin{array}{c}700.05 \\
(614.22- \\
839.72)\end{array}$ & $0.245^{*}$ \\
\hline $\begin{array}{c}C x . \\
\text { quinquefasciatus }\end{array}$ & $21.6 \pm 2.07^{\mathrm{a}}$ & $33.0 \pm 1.41^{\mathrm{b}}$ & $45.4 \pm 2.30^{\mathrm{c}}$ & $59.6 \pm 2.60^{d}$ & $70.8 \pm 3.03^{\mathrm{e}}$ & $\begin{array}{c}332.76 \\
(298.52- \\
370.65)\end{array}$ & $\begin{array}{c}715.34 \\
(627.96- \\
857.01)\end{array}$ & $0.034 *$ \\
\hline
\end{tabular}

951 Mortality rates aremeans \pm SD of triplicate replicates. No mortality was observed in the control. Within each

952 column means followed by the same letter(s) are not significantly different $(\mathrm{P}<0.05)$. $\mathrm{LC}_{50}$ lethal concentration that kills $50 \%$ of the exposed organisms, $\mathrm{LC}_{90}$ lethal concentration that kills $90 \%$ of the exposed organisms, LCL lower confidence limit, UCL upper confidence limit. Chi-square value followed by an asterisk is 955 significant $(\mathrm{P}<0.05)$ 
Table 14: Adulticidal effect of acetone leaf extract of Smilax zeylanica on the malarial, dengue and filarial vector.

\begin{tabular}{|c|c|c|c|c|c|c|c|c|}
\hline \multirow{3}{*}{$\begin{array}{c}\text { Targeted } \\
\text { mosquito } \\
\text { species }\end{array}$} & \multicolumn{5}{|c|}{ Mortality $(\%)(\operatorname{mean} \pm$ SD $)$} & \multirow{3}{*}{$\begin{array}{c}\mathbf{L C}_{50} \\
\text { ppm } \\
\text { (LFL- } \\
\text { UFL) }\end{array}$} & \multirow{3}{*}{$\begin{array}{c}\mathbf{L C}_{90} \\
\text { ppm } \\
\text { (LFL- } \\
\text { UFL) }\end{array}$} & \multirow{3}{*}{$\chi^{2}$} \\
\hline & \multicolumn{5}{|c|}{ Concentration(ppm) } & & & \\
\hline & 100 & 200 & 300 & 400 & 500 & & & \\
\hline An. stephensi & $31.4 \pm 2.07^{\mathrm{a}}$ & $45.6 \pm 2.40^{\mathrm{b}}$ & $56.8 \pm 2.38^{c}$ & $71.0 \pm 1.22^{\mathrm{d}}$ & $79.2 \pm 1.92^{\mathrm{e}}$ & $\begin{array}{c}241.97 \\
(199.70- \\
277.31)\end{array}$ & $\begin{array}{c}634.40 \\
(557.76- \\
759.05)\end{array}$ & $0.213^{*}$ \\
\hline Ae. aegypti & $27.6 \pm 2.07^{\mathrm{a}}$ & $42.2 \pm 1.92^{b}$ & $53.1 \pm 1.67^{\mathrm{c}}$ & $67.5 \pm 1.93^{d}$ & $76.4 \pm 1.81^{\mathrm{e}}$ & $\begin{array}{c}271.61 \\
(233.31- \\
306.57)\end{array}$ & $\begin{array}{c}662.33 \\
(581.90- \\
793.11)\end{array}$ & $0.273^{*}$ \\
\hline $\begin{array}{c}C x . \\
\text { quinquefasciatus }\end{array}$ & $24.2 \pm 1.92^{\mathrm{a}}$ & $38.1 \pm 2.40^{\mathrm{b}}$ & $49.4 \pm 1.67^{\mathrm{c}}$ & $63.2 \pm 2.16^{\mathrm{d}}$ & $72.3 \pm 2.86^{\mathrm{e}}$ & $\begin{array}{c}304.99 \\
(268.61- \\
341.93)\end{array}$ & $\begin{array}{c}703.03 \\
(614.86- \\
848.18)\end{array}$ & $0.293^{*}$ \\
\hline
\end{tabular}

Mortality rates are means \pm SD of triplicate. No mortality was observed in the control. Within each column means followed by the same letter(s) are not significantly different $(\mathrm{P}<0.05) . \mathrm{LC}_{50}$ lethal concentration that kills $50 \%$ of the exposed organisms, $\mathrm{LC}_{90}$ lethal concentration that kills $90 \%$ of the exposed organisms, LCL lower confidence limit, UCL upper confidence limit. Chi-square value followed by an asterisk is significant 
Table 15: Adulticidal effect of ethanol leaf extract of Smilax zeylanica on the malarial, dengue and filarial vector

\begin{tabular}{|c|c|c|c|c|c|c|c|c|}
\hline \multirow{3}{*}{$\begin{array}{c}\text { Targeted } \\
\text { mosquito } \\
\text { species }\end{array}$} & \multicolumn{5}{|c|}{ Mortality $(\%)($ mean \pm SD $)$} & \multirow{3}{*}{$\begin{array}{l}\mathrm{LC}_{50} \\
\mathrm{ppm} \\
\text { (LFL- } \\
\text { UFL) }\end{array}$} & \multirow{3}{*}{$\begin{array}{c}\mathrm{LC}_{90} \\
\text { ppm } \\
\text { (LFL- } \\
\text { UFL) }\end{array}$} & \multirow{3}{*}{$\chi^{2}$} \\
\hline & \multicolumn{5}{|c|}{ Concentration(ppm) } & & & \\
\hline & 100 & 200 & 300 & 400 & 500 & & & \\
\hline An. stephensi & $33.1 \pm 2.07^{\mathrm{a}}$ & $49.4 \pm 2.40^{b}$ & $60.2 \pm 1.92^{\mathrm{c}}$ & $74.7 \pm 2.38^{\mathrm{d}}$ & $84.0 \pm 1.58^{\mathrm{e}}$ & $\begin{array}{c}217.12 \\
(174.75- \\
251.02)\end{array}$ & $\begin{array}{c}578.86 \\
(514.60- \\
679.35)\end{array}$ & $0.257^{*}$ \\
\hline Ae. aegypti & $30.0 \pm 2.00^{\mathrm{a}}$ & $45.8 \pm 1.78^{b}$ & $57.4 \pm 2.07^{\mathrm{c}}$ & $71.3 \pm 2.22^{\mathrm{d}}$ & $81.5 \pm 1.51^{\mathrm{e}}$ & $\begin{array}{c}241.89 \\
(202.80- \\
275.02)\end{array}$ & $\begin{array}{c}607.15 \\
(538.79- \\
714.60)\end{array}$ & $0.176^{*}$ \\
\hline $\begin{array}{c}C x . \\
\text { quinquefasciatus }\end{array}$ & $28.5 \pm 1.61^{\mathrm{a}}$ & $41.2 \pm 2.16^{\mathrm{b}}$ & $54.0 \pm 2.12^{c}$ & $67.6 \pm 2.07^{\mathrm{d}}$ & $78.8 \pm 1.92^{\mathrm{e}}$ & $\begin{array}{c}266.90 \\
(229.70- \\
300.55)\end{array}$ & $\begin{array}{c}642.43 \\
(567.51- \\
761.88)\end{array}$ & $0.013^{*}$ \\
\hline
\end{tabular}

Mortality rates are means \pm SD of triplicate. No mortality was observed in the control. Within each column means followed by the same letter(s) are not significantly different $(\mathrm{P}<0.05)$. $\mathrm{LC}_{50}$ lethal concentration that kills $50 \%$ of the exposed organisms, $\mathrm{LC}_{90}$ lethal concentration that kills $90 \%$ of the exposed organisms, LCL lower confidence limit, UCL upper confidence limit. Chi-square value followed by an asterisk is significant 
Table 16: Repellent activity of of p.ether, acetone and ethanol leaf extracts of Smilax zeylanica against An. stephensi

\begin{tabular}{|c|c|c|c|c|c|c|c|}
\hline \multirow{3}{*}{$\begin{array}{c}\text { Plant solvent } \\
\text { extracts }\end{array}$} & \multirow{3}{*}{$\begin{array}{l}\text { Concentration } \\
\left(\mathbf{m g} / \mathrm{cm}^{2}\right)\end{array}$} & \multicolumn{6}{|c|}{$\%$ of Repellency \pm SD } \\
\hline & & \multicolumn{6}{|c|}{ Time post application of repellent (min) } \\
\hline & & 60 & 90 & 120 & 150 & 180 & 210 \\
\hline \multirow{3}{*}{$\begin{array}{l}\text { Petroleum } \\
\text { ether }\end{array}$} & 0.5 & $100.0 \pm 0.0$ & $100.0 \pm 0.0$ & $100.0 \pm 0.0$ & $100.0 \pm 0.0$ & $100.0 \pm 0.0$ & $87.6 \pm 1.34$ \\
\hline & 1.0 & $100.0 \pm 0.0$ & $100.0 \pm 0.0$ & $100.0 \pm 0.0$ & $100.0 \pm 0.0$ & $100.0 \pm 0.0$ & $93.4 \pm 2.07$ \\
\hline & 1.5 & $100.0 \pm 0.0$ & $100.0 \pm 0.0$ & $100.0 \pm 0.0$ & $100.0 \pm 0.0$ & $100.0 \pm 0.0$ & $100.0 \pm 0.0$ \\
\hline \multirow{3}{*}{ Acetone } & 0.5 & $100.0 \pm 0.0$ & $100.0 \pm 0.0$ & $100.0 \pm 0.0$ & $100.0 \pm 0.0$ & $100.0 \pm 0.0$ & $91.2 \pm 0.83$ \\
\hline & 1.0 & $100.0 \pm 0.0$ & $100.0 \pm 0.0$ & $100.0 \pm 0.0$ & $100.0 \pm 0.0$ & $100.0 \pm 0.0$ & $96.6 \pm 2.07$ \\
\hline & 1.5 & $100.0 \pm 0.0$ & $100.0 \pm 0.0$ & $100.0 \pm 0.0$ & $100.0 \pm 0.0$ & $100.0 \pm 0.0$ & $100.0 \pm 0.0$ \\
\hline \multirow{3}{*}{ Ethanol } & 0.5 & $100.0 \pm 0.0$ & $100.0 \pm 0.0$ & $100.0 \pm 0.0$ & $100.0 \pm 0.0$ & $100.0 \pm 0.0$ & $94.7 \pm 0.8$ \\
\hline & 1.0 & $100.0 \pm 0.0$ & $100.0 \pm 0.0$ & $100.0 \pm 0.0$ & $100.0 \pm 0.0$ & $100.0 \pm 0.0$ & $98.2 \pm 1.48$ \\
\hline & 1.5 & $100.0 \pm 0.0$ & $100.0 \pm 0.0$ & $100.0 \pm 0.0$ & $100.0 \pm 0.0$ & $100.0 \pm 0.0$ & $100.0 \pm 0.0$ \\
\hline
\end{tabular}


Table 17: Repellent activity of p.ether, acetone and ethanol leaf extracts of Smilax zeylanica against Ae. aegypti

\begin{tabular}{|c|c|c|c|c|c|c|c|}
\hline \multirow{3}{*}{$\begin{array}{c}\text { Plant solvent } \\
\text { extracts }\end{array}$} & \multirow{3}{*}{$\begin{array}{l}\text { Concentration } \\
\left(\mathbf{m g} / \mathrm{cm}^{2}\right)\end{array}$} & \multicolumn{6}{|c|}{$\%$ of Repellency \pm SD } \\
\hline & & \multicolumn{6}{|c|}{ Time post application of repellent (min) } \\
\hline & & 60 & 90 & 120 & 150 & 180 & 210 \\
\hline \multirow{3}{*}{$\begin{array}{l}\text { Petroleum } \\
\text { ether }\end{array}$} & 0.5 & $100.0 \pm 0.0$ & $100.0 \pm 0.0$ & $100.0 \pm 0.0$ & $100.0 \pm 0.0$ & $100.0 \pm 0.0$ & $82.3 \pm 1.34$ \\
\hline & 1.0 & $100.0 \pm 0.0$ & $100.0 \pm 0.0$ & $100.0 \pm 0.0$ & $100.0 \pm 0.0$ & $100.0 \pm 0.0$ & $92.1 \pm 2.07$ \\
\hline & 1.5 & $100.0 \pm 0.0$ & $100.0 \pm 0.0$ & $100.0 \pm 0.0$ & $100.0 \pm 0.0$ & $100.0 \pm 0.0$ & $100.0 \pm 0.0$ \\
\hline \multirow{3}{*}{ Acetone } & 0.5 & $100.0 \pm 0.0$ & $100.0 \pm 0.0$ & $100.0 \pm 0.0$ & $100.0 \pm 0.0$ & $100.0 \pm 0.0$ & $87.8 \pm 0.83$ \\
\hline & 1.0 & $100.0 \pm 0.0$ & $100.0 \pm 0.0$ & $100.0 \pm 0.0$ & $100.0 \pm 0.0$ & $100.0 \pm 0.0$ & $94.4 \pm 2.07$ \\
\hline & 1.5 & $100.0 \pm 0.0$ & $100.0 \pm 0.0$ & $100.0 \pm 0.0$ & $100.0 \pm 0.0$ & $100.0 \pm 0.0$ & $100.0 \pm 0.0$ \\
\hline \multirow{3}{*}{ Ethanol } & 0.5 & $100.0 \pm 0.0$ & $100.0 \pm 0.0$ & $100.0 \pm 0.0$ & $100.0 \pm 0.0$ & $100.0 \pm 0.0$ & $91.2 \pm 2.07$ \\
\hline & 1.0 & $100.0 \pm 0.0$ & $100.0 \pm 0.0$ & $100.0 \pm 0.0$ & $100.0 \pm 0.0$ & $100.0 \pm 0.0$ & $95.3 \pm 1.48$ \\
\hline & 1.5 & $100.0 \pm 0.0$ & $100.0 \pm 0.0$ & $100.0 \pm 0.0$ & $100.0 \pm 0.0$ & $100.0 \pm 0.0$ & $100.0 \pm 0.0$ \\
\hline
\end{tabular}

Values were means $\pm \mathrm{SD}$ of five replicates. 
Table 18: Repellent activity of p.ether, acetone and ethanol leaf extracts of Smilax zeylanica against, $C x$. quinquefasciatus

\begin{tabular}{|c|c|c|c|c|c|c|c|}
\hline \multirow{3}{*}{$\begin{array}{c}\text { Plant solvent } \\
\text { extracts }\end{array}$} & \multirow{3}{*}{$\begin{array}{l}\text { Concentration } \\
\left(\mathbf{m g} / \mathrm{cm}^{2}\right)\end{array}$} & \multicolumn{6}{|c|}{$\%$ of Repellency \pm SD } \\
\hline & & \multicolumn{6}{|c|}{ Time post application of repellent (min) } \\
\hline & & 60 & 90 & 120 & 150 & 180 & 210 \\
\hline \multirow{3}{*}{$\begin{array}{l}\text { Petroleum } \\
\text { ether }\end{array}$} & 0.5 & $100.0 \pm 0.0$ & $100.0 \pm 0.0$ & $100.0 \pm 0.0$ & $100.0 \pm 0.0$ & $90.5 \pm 1.34$ & $81.2 \pm 1.34$ \\
\hline & 1.0 & $100.0 \pm 0.0$ & $100.0 \pm 0.0$ & $100.0 \pm 0.0$ & $100.0 \pm 0.0$ & $96.1 \pm 2.07$ & $89.4 \pm 2.07$ \\
\hline & 1.5 & $100.0 \pm 0.0$ & $100.0 \pm 0.0$ & $100.0 \pm 0.0$ & $100.0 \pm 0.0$ & $100.0 \pm 0.0$ & $93.2 \pm 1.48$ \\
\hline \multirow{3}{*}{ Acetone } & 0.5 & $100.0 \pm 0.0$ & $100.0 \pm 0.0$ & $100.0 \pm 0.0$ & $100.0 \pm 0.0$ & $93.1 \pm 0.83$ & $84.6 \pm 0.83$ \\
\hline & 1.0 & $100.0 \pm 0.0$ & $100.0 \pm 0.0$ & $100.0 \pm 0.0$ & $100.0 \pm 0.0$ & $98.8 \pm 2.07$ & $91.3 \pm 2.07$ \\
\hline & 1.5 & $100.0 \pm 0.0$ & $100.0 \pm 0.0$ & $100.0 \pm 0.0$ & $100.0 \pm 0.0$ & $100.0 \pm 0.0$ & $95.3 \pm 1.34$ \\
\hline \multirow{3}{*}{ Ethanol } & 0.5 & $100.0 \pm 0.0$ & $100.0 \pm 0.0$ & $100.0 \pm 0.0$ & $100.0 \pm 0.0$ & $100.0 \pm 0.0$ & $89.4 \pm 2.07$ \\
\hline & 1.0 & $100.0 \pm 0.0$ & $100.0 \pm 0.0$ & $100.0 \pm 0.0$ & $100.0 \pm 0.0$ & $100.0 \pm 0.0$ & $97.2 \pm 1.48$ \\
\hline & 1.5 & $100.0 \pm 0.0$ & $100.0 \pm 0.0$ & $100.0 \pm 0.0$ & $100.0 \pm 0.0$ & $100.0 \pm 0.0$ & $100.0 \pm 0.0$ \\
\hline
\end{tabular}


1030

1031

Topic: Molecular interaction of novel phytocompounds from Smilax zeylanica (L) against the targeted protein of mosquito vectors and their potential activity

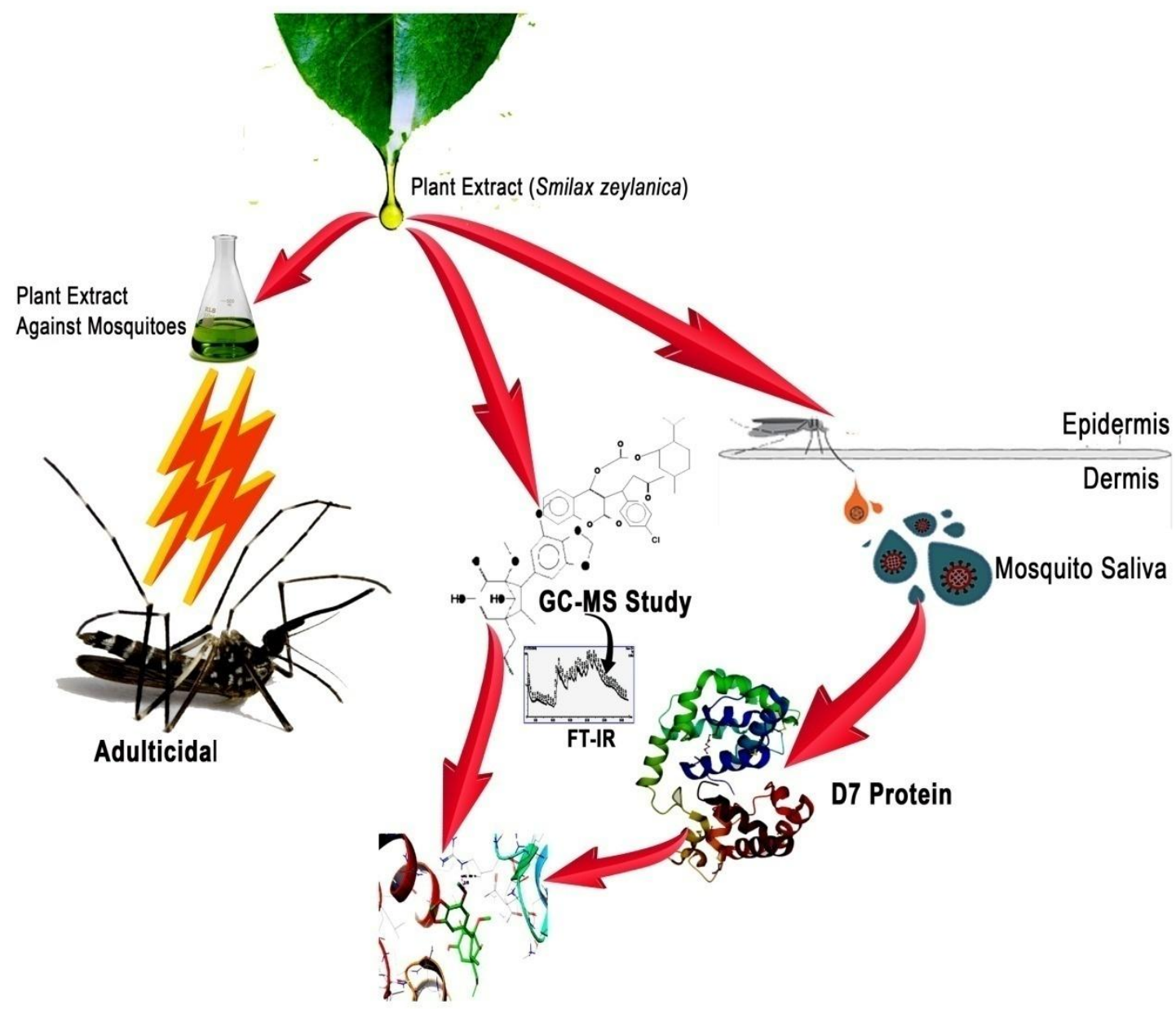

Molecular docking interaction mechanism of D7 salivary protein and odorant binding proteins 